\title{
Tropical Andosol organic carbon quality and degradability in relation to soil geochemistry as affected by land use
}

\author{
Sastrika Anindita ${ }^{1}$, Peter Finke $^{1}$, Steven Sleutel $^{1}$ \\ ${ }^{1}$ Department of Environment, Ghent University, Ghent, 9000, Belgium \\ 5 Correspondence to: Sastrika Anindita (sastrika.anindita@ugent.be)
}

\begin{abstract}
Land use is recognized to impact soil geochemistry on the centennial to millennial time scale, with implications for the distribution and stability of soil organic carbon (SOC). Juvenile volcanic soils in tropical areas are subject to much faster pedogenesis, with then also possibly a significant mediation by land use on much shorter centennial or even decadal scale. Very scarce observational evidence exists and so such indirect implications of land use on SOC cycling are largely unknown. We here investigated SOC fractions, substrate specific mineralization (SOC or added plant residue), and net priming of SOC in function of forest or agricultural land use on Indonesian volcanic soils. The content of oxalate-extracted $\mathrm{Al}$ and exchangeable $\mathrm{Ca}$ correlated well with $\mathrm{OC}$ associated with sand-sized aggregates. The concomitant near doubling of the proportion of SOC in sand-sized aggregates compared to forest and likewise contrasts in $\mathrm{Al}$ and $\mathrm{Ca}$ suggest an enhanced formation of Al- (hydr)oxides and liming promoted aggregation and physical occlusion of OC. This was importantly also

15 consistent with a relatively lesser degradability of SOC in the agricultural sites, though the net priming of SOC and degradability of added ${ }^{13} \mathrm{C}$-labelled ryegrass was not found to depend on land use. We expected that the formation of amorphous $\mathrm{Al}$ after conversion of native forest to agriculture would mainly have promoted mineral-association of SOC compared to under pine forest but found no indications for this. Enhanced weathering but improved small scale aggregation of tropical Andosols caused by conversion to agriculture may thus partially counter the otherwise expectable decline of SOC

20 stocks following cultivation. Such indirect land use effects on the SOC balance appeared relevant for correct interpretation and prediction of the long-term C-balance of (agro)ecosystems with soil subject to intense development, like the here studied tropical Andosols.
\end{abstract}

\section{Introduction}

Storage of soil organic carbon (SOC) in terrestrial ecosystems can improve ecosystem services such as soil health, 25 agricultural productivity, and climate change mitigation (Baldock, 2007; Lehmann and Kleber, 2015). The storage of SOC is influenced by the interaction of ecological processes with net primary productivity and heterotrophic respiration usually being most important terms of the SOC balance. Land use determines the net-C input to soil and in doing so often bears an overriding control on the SOC balance, compared to other drivers of the C-cycle at ecosystem level. Forest ecosystems usually have relatively high net primary productivity compared to agricultural land use (Smith et al., 2014). The net result of 
https://doi.org/10.5194/soil-2022-13

Preprint. Discussion started: 24 February 2022

(c) Author(s) 2022. CC BY 4.0 License.

(c) (i)

30 cultivation then typically leads to a decline in SOC stock and increased human-induced $\mathrm{CO}_{2}$ emission (Don et al., 2011; Wei et al., 2014). The long-term SOC balance of ecosystems also depends on the capacity of soils to stabilize newly entering OC against microbial decomposition, resulting from heterotrophic respiration. Physical occlusion of OC at the microaggregate scale as well as binding of OC onto reactive mineral surfaces constitute two major mechanisms for stabilization of SOC (Matus et al., 2014). Soil characteristics such as content of poorly crystalline minerals, specific surface area, clay content and

35 degree of soil micro-aggregation have all been linked to the capacity of soils to accumulate SOC (Hernández et al., 2012; Kleber et al., 2015; Mikutta et al., 2006, 2009; Poirier et al., 2020). While soil mineralogy itself is thus a well-recognized controller of SOC stabilization, surprisingly little attention has gone into understanding how land use history, through its impact on soil geochemistry might in turn indirectly control stability of SOC and organic matter (OM) entering soil.

40 The geochemistry of the reactive mineral phase of a soil is the resultant of both the composition of its parent material and soil weathering status (Mikutta et al., 2009). Weathering status is crucially driven by the time since the onset of weathering, local climate and hydrologic conditions, resilience of minerals to weathering and vegetation cover (Doetterl et al., 2015). Land use, through its control on vegetation, can impact the weathering process by modifying the $\mathrm{pH}$, influencing soil biological activity and nutrient levels, and releasing organic complexing compounds (Van Breemen et al., 1983; Cronan,

45 2018). On agricultural lands, moreover fertilizer addition and soil disturbance caused by tillage have also been reported to significantly enhance weathering (Churchman and Lowe, 2012; Li et al., 2021; Taylor et al., 2016). While an extensive and still growing number of studies considered land use impacts on SOC stock, soil OM quality and its degradability (Covaleda et al., 2011; Cusack et al., 2013; Huygens et al., 2005), just very few of have considered the potential indirect impact of land use on SOC stability through its effect on the soil mineral phase. Moreover, the coverage remains limited for several soil

50 groups, including tropical Andosols. A recent study on the Gálápagos islands demonstrated that even within a few centuries to just several decades conversion of native forest to cultivated land strikingly accelerated soil weathering (Gerzabek et al., 2019). In particular, formation of secondary minerals should impact SOC retention in volcanic soils as their high capacity to do so is acknowledged to emerge from abundantly present poorly crystalline Al and Fe oxides. Indeed, Asano and Wagai (2014) concluded the importance of short-range order minerals or organo-Al complexes for SOC stabilization in Andosols

55 from correlations with OC stock (Miyazawa et al., 2013), mean residence time (reviewed by Parfitt (2009)), and by chemical characterization of organo-mineral associations (Basile-Doelsch et al., 2007; Mikutta et al., 2009). Next to a large specific surface area, also microaggregation and occlusion therein of intra-microaggregate particulate OM (iPOM) is known to grant a degree of protection against its microbial decay (Six et al., 2000a), particularly in Andosols (Asano et al., 2018; Asano and Wagai, 2014). Introduction of tillage and removal of permanent vegetative coverage usually adversely affect iPOM-induced 60 physical protection. However, differences between untilled native vegetation or secondary forest on the one hand and tilled cropland might not be significant for volcanic soils (Dörner et al., 2012; Huygens et al., 2005; Linlin et al., 2016) as abundant nano sized organo-mineral composites overridingly act as binding agents in microaggregates in Andosols (Asano and Wagai, 2015). 
65 In Indonesia, the Sunda volcanic arc region (Mt. Tangkuban Perahu and Mt. Burangrang) in West Java, was covered by native forest until only about two centuries back but has since then been largely replaced by secondary pine forest or agricultural land use. With differently aged volcanic deposits and co-occurrence of native forest, secondary forest and cultivated land this region forms a useful means to understand how Andosol development would impact SOC storage and stability. A first objective was to further investigate how cultivation history in this region would have resulted in differential soil aggregation and levels of $\mathrm{PPOM}$, and mineral associated OM vs. free relatively unprotected OM. We did so by assessing soil OM fractions for a set of 6 Indonesian volcanic soil (Cambisols and Andosols) with native forest, secondary pine forest or agricultural land use. A second goal was to infer how OM degradability in the topsoil of these tropical volcanic soils itself differs in function of forest vs. agricultural land use. Assessing the indirect effect of land use on SOC degradability through its mediation of soil mineralogy is, however, complicated by the fact that quality of native SOC itself is also function of land use. We therefore assessed the degradability of a single model exogenous $\mathrm{OM}$ source $\left({ }^{13} \mathrm{C}\right.$-labelled ryegrass residues) to see how land use changes affect stability of $\mathrm{OC}$ in soil. We hypothesize that the enhanced formation of pedogenic poorly crystalline $\mathrm{Al}$ under agricultural land use, as we previously confirmed (Anindita et al., under review), results in a relative stabilization of the exogenous OM as compared to native forest or secondary forest. In doing so we take account for the wellknown phenomenon that labile OC-inputs can accelerate the decomposition of native SOC, a process called positive priming (Chen et al., 2014), or conversely restrain decomposition of SOC and induce negative priming (Blagodatskaya et al., 2014; Qiao et al., 2014). By using a C-isotope mixing model, mineralization of the exogenous OM (i.e.ryegrass) and native SOC are distinguished in the soil incubation experiments.

\section{Materials and methods}

\subsection{Site description and soil sampling}

85 Our study covered soils from the Mount Tangkuban Perahu and Mount Burangrang regions that are part of the Sunda Volcanic complex in West Java, Indonesia. The mean annual temperature in this region is $19-21^{\circ} \mathrm{C}$ and mean annual precipitation ranges around 2000-3000 mm per year. Six sites were selected to represent the dominant land use types in the area, viz. primary forest (NF), pine forest (PF1 and PF2) and horticulture (AG1, AG2, and AG3). Soils at sites NF and PF1 are andic Cambisols and at the PF2, AG1, AG2, AG3 sites aluandic Andosols (Anindita et al., under review). All soils

90 contain silicate minerals (i.e. quartz, cristobalite, tridymite), gibbsite, albite, hornblende, 1:1 clay minerals, and noncrystalline materials (Anindita et al., under review). The proportion of primary minerals is higher in the younger NF soil as it is closer (within $1.5 \mathrm{~km}$ ) to the crater of Mt. Tangkuban Perahu and received ash more recently. The pine forest and agricultural sites were originally all under the primary forest vegetation. At PF1 and PF2, secondary forests were planted in 1962 for restoration purposes, following earlier deforestation. Agricultural land use at AG1, AG2, and AG3 dates back to

95 just 30-50 years ago with mainly diverse horticultural crop rotations with crops potatoes (Solanum tuberosum), cabbage 
(Brassica oleracea), green bean (Phaseolus vulgaris), tomatoes (Solanum lycopersicum), and chayote (Sechium edule). Detailed information about land use history, and land management are given in Anindita et al. (under review).

At every site, soil samples were taken at 0-20, 20-40, and 60-80 cm depth. At each depth, the bulk samples were mixed into composite ones, which were then dried to the air, homogenised and sieved $(<2 \mathrm{~mm})$ until further analysis at the Dept. of Environment of Ghent University (Belgium). The pH H2O was measured using a glass electrode $\mathrm{pH}$ meter in a 1:5 soil solution slurry. The estimated clay content was determined using the pipet method after full soil dispersion with Na+-resin (Bartoli et al., 1991), after testing several other procedures for soil texture analysis that proved incompatible with the investigated set of volcanic soils. The concentrations of total $\mathrm{C}$ and $\mathrm{N}$ were determined by dry combustion at $1100^{\circ} \mathrm{C}$ using a

105 LECO 928 series $\mathrm{CN}$-analyser. Aluminum extracted by $0.1 \mathrm{M}$ pyrophosphate solution $\left(\mathrm{Al}_{\mathrm{p}}\right)$ was taken as measure of complexed $\mathrm{Al}$ to $\mathrm{OM}$ (McKeague, 1967). Iron and aluminum extractable by ammonium oxalate $\left(\mathrm{Al}_{0}, \mathrm{Fe}_{\mathrm{o}}\right)$ were used as estimates of X-ray amorphous $\mathrm{Al}$ and $\mathrm{Fe}$. We previously quantified crystalline minerals using $\mathrm{X}$-ray diffraction analysis. The amount of amorphous materials undetectable by X-ray diffraction was semi-quantitatively estimated from the difference between the obtained and the real amount of internal standard (Zincite 20\%) after semi-quantification of crystalline minerals

110 using BGMN Rietveld and Profex as user interface. Soil specific surface area (SSA) was assessed from adsorptiondesorption of $\mathrm{N}_{2}$ at $77^{\circ} \mathrm{C}$ following Brunauer-Emmett-Teller (BET) approach. Detailed methods and the results of geochemical analyses of the samples were documented in Anindita et al. (under review). Selected physicochemical soil properties are given in Table 1.

115 Table 1. Physicochemical soil properties of 6 sampled soil profiles in the Sunda Volcanic complex in West Java, Indonesia (partly taken from Anindita et al. (under review))

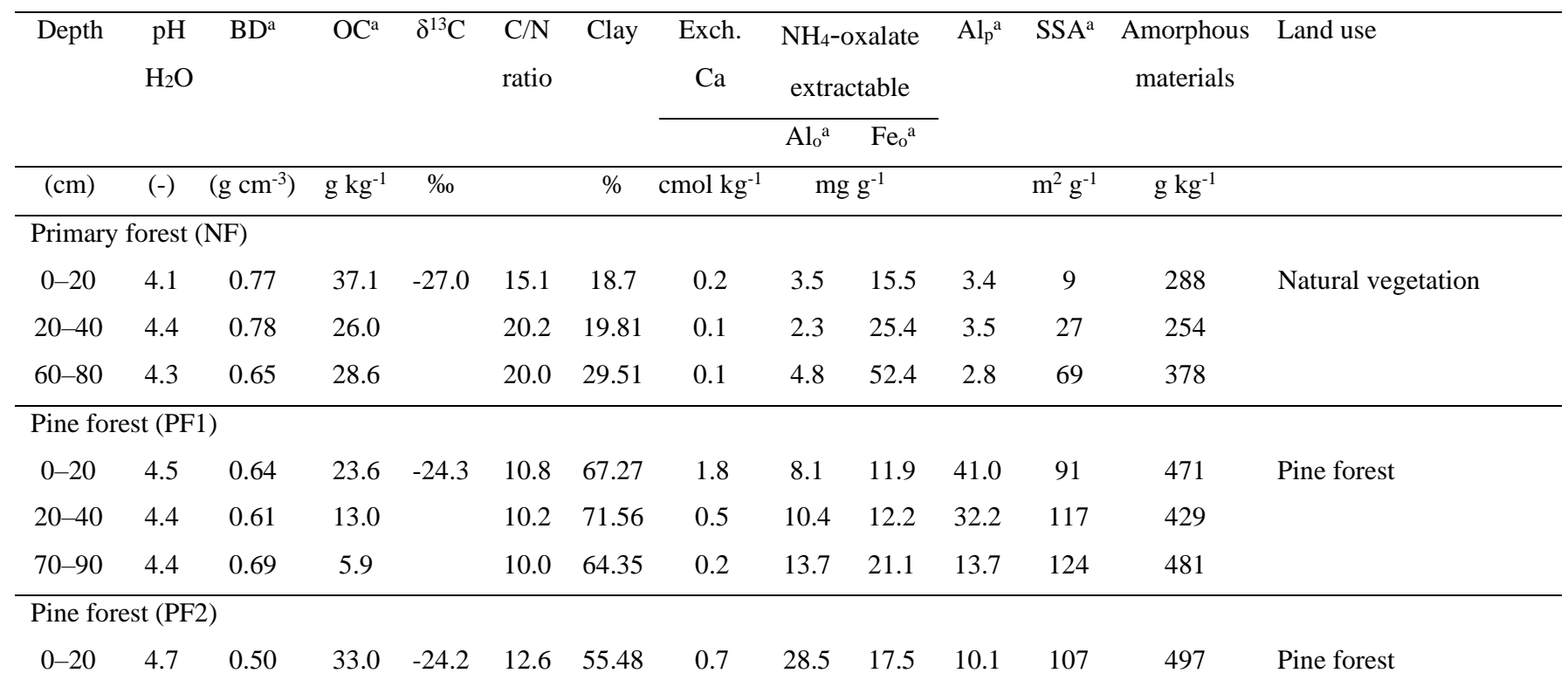


https://doi.org/10.5194/soil-2022-13

Preprint. Discussion started: 24 February 2022

(c) Author(s) 2022. CC BY 4.0 License.

$\begin{array}{llllllllllll}20-40 & 4.9 & 0.56 & 18.2 & 12.2 & 46.43 & 0.4 & 27.7 & 17.2 & 9.8 & 145 & 506 \\ 60-80 & 4.4 & 0.60 & 15.7 & 11.9 & 48.82 & 0.4 & 25.9 & 17.5 & 9.4 & 127 & 447\end{array}$

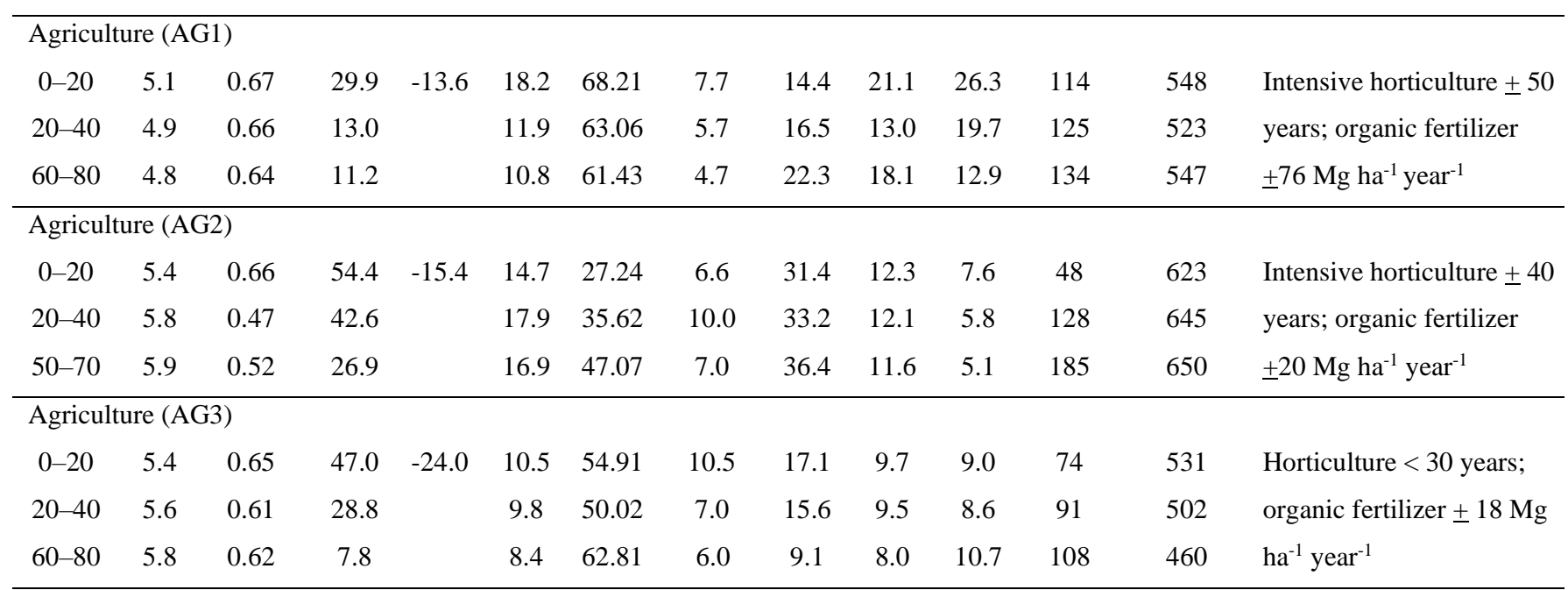

${ }_{\mathrm{a}}^{\mathrm{B} D}=$ bulk density; $\mathrm{OC}=$ organic carbon; $\mathrm{Al}_{\mathrm{o}}=$ aluminum extracted by $\mathrm{NH}_{4}$-oxalate; $\mathrm{Fe}_{\mathrm{o}}=$ iron extracted by $\mathrm{NH}_{4}-\mathrm{oxalate}_{\mathrm{A}} \mathrm{Al}_{\mathrm{p}}=$ aluminum extracted by Na-pyrophosphate; SSA = specific surface area

\subsection{Soil organic matter fractionation}

120 Soils were fractionated using size, density and chemical separation steps according to Zimmermann et al. (2007). This procedure separates SOC into five pools, namely into i) OC contained in soil aggregates and associated with sand (S+A), ii) in free particulate organic matter (POM), iii) in water dissolvable OC (DOC), iv) in oxidizable OC associated with the silt and clay $(\mathrm{s}+\mathrm{c}-\mathrm{rSOC})$ fraction, and $\mathrm{v})$ in a chemically resistant SOC (rSOC) pool. Briefly, $30 \mathrm{~g}$ of equivalent dry soil $(<2$ $\mathrm{mm}$ ) was dispersed in water by a calibrated ultrasonic probe with an output energy of $22 \mathrm{~J} \mathrm{ml}^{-1}$. The resulting slurries were

125 wet-sieved over a $63 \mu \mathrm{m}$ sieve and rinsed with deionized water until the rinsing water became clear. In the original Zimmermann et al. (2007) method the $>63 \mu \mathrm{m}$ fraction is further separated into S+A and POM based on density differences using sodium polytungstate at $1.8 \mathrm{~g} \mathrm{~cm}^{-3}$. However, several samples could not be well separated into free OM on the one hand and predominantly mineral material of the S+A fraction on the other. After pre-tests we instead used a $1.5 \mathrm{~g} \mathrm{~cm}^{-3}$ sodium polytungstate solution to separate free POM from the S+A soil fraction, as per Cerli et al. (2012)'s advise to per soil

130 optimize density cut-off for best separation of free and occluded POM. A subsample of the $<63 \mu \mathrm{m}$ suspension $( \pm 10 \mathrm{ml})$ derived from the wet sieving step was filtered through a $0.45 \mu \mathrm{m}$ nylon membrane filter. The filtrate was analyzed for its dissolved OC concentration using a HT-I Formacs TOC-analyzer (Skalar, The Netherlands). The DOC pool was calculated by multiplying this OC concentration with the volume of flush water used in the preceding wet sieving step. The $<63 \mu \mathrm{m}$ suspension was dried at $40^{\circ} \mathrm{C}$ and weighted to constitute the overall silt+clay $(\mathrm{s}+\mathrm{c})$ fraction. A chemically inert share of the

135 SOC ( $\mathrm{rSOC}$ ) was isolated by subjecting the $\mathrm{s}+\mathrm{c}$ fraction to oxidation by $6 \% \mathrm{NaOCl}$. To this end, one gram of $\mathrm{s}+\mathrm{c}$ material was weighted inside a $65 \mathrm{ml} \mathrm{Nalgene} \mathrm{centrifuge} \mathrm{tube} \mathrm{and} 50 \mathrm{ml} 6 \% \mathrm{NaOCl}$ adjusted to $\mathrm{pH} 8$ was added and allowed to react 
https://doi.org/10.5194/soil-2022-13

Preprint. Discussion started: 24 February 2022

(c) Author(s) 2022. CC BY 4.0 License.

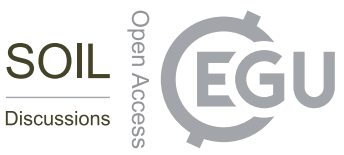

for $18 \mathrm{~h}$ at $25^{\circ} \mathrm{C}$. After centrifugation, remnant $\mathrm{NaOCl}$ was discarded by decantation. This procedure was repeated three times, the pellet was washed three more times with deionized water, transferred to a pre-weighted aluminum cup, dried at $40^{\circ} \mathrm{C}$ and weighted. All fractions were analyzed for their C concentration using a LECO 928 series $\mathrm{CN}$-analyzer. Further details are given in Zimmermann et al. (2007) and Poeplau et al. (2013).

\subsection{Soil incubation experiment and isotopic signature measurements}

Soils were incubated in a standardized way to compare degradability of a model plant-C substrate and SOC in the topsoil (0$20 \mathrm{~cm}$ ) of the 6 considered sites. Decomposition of either substrate was derived by regular measurement of the $\mathrm{soil}^{\mathrm{CO}_{2}}$ efflux and inference of its $\delta^{13} \mathrm{C}$ signature. Soil mesocosms were prepared by repacking approximately $150 \mathrm{~g}$ of soil (depending on bulk density) into PVC tubes (diameter: $6.8 \mathrm{~cm}$, height: $7 \mathrm{~cm}$ ) to reach a height of $6.2 \mathrm{~cm}$ and bulk density as encountered at the field sites. Soil moisture content was set to $50 \%$ water-filled pore space by addition of deionized water. A ${ }^{13} \mathrm{C}$-labelled plant-substrate, i.e. pulse-labelled ryegrass (Lolium perenne) with $\delta^{13} \mathrm{C}$ of $+53.7 \%$, was applied at a dose of 1 $\mathrm{g} \mathrm{kg}^{-1}$ of dry matter. The contrast in $\delta^{13} \mathrm{C}$ with SOC (Table 1) allowed to distinguish emitted $\mathrm{CO}_{2}$ into parts stemming from either native SOC or grass-C mineralization. The $\delta^{13} \mathrm{C}$ of topsoil (expressed as $\delta^{13} \mathrm{C}$ value (\%) vs. the international Vienna Pee Dee Belemnite standard) was measured using a PDZ Europe ANCA-GSL elemental analyser, interfaced with a Sercon 20-22 IRMS with SysCon electronics (SetCon, Ceshire, UK).

Soils were incubated at $20^{\circ} \mathrm{C}$ for 120 days. On days $1,3,5,8,12,17,24,32,38,47,59,73,87,101,111,120{\text { soil } \mathrm{CO}_{2}}$ emission was inferred by measuring $\mathrm{CO}_{2}$ build-up in a cylindrical closed-chamber attached consecutively on top of each

155 PVC tube for at least $10 \mathrm{~min}$. The evolution of the headspace $\mathrm{CO}_{2}$ concentration and its $\delta^{13} \mathrm{C}$ was measured every 4 sec by connecting the closed-chamber with a cavity ring-down spectrometer (G2201-i CRDS isotopic $\mathrm{CO}_{2}$ analyser, Picarro, USA) in a loop via Teflon tubing. Soil $\mathrm{CO}_{2}$ efflux rate in $\mathrm{mg} \mathrm{C} \mathrm{kg}^{-1} \mathrm{~h}^{-1}$ was calculated from the slope of the accumulating $\mathrm{CO}_{2}$ concentration in function of time using the ideal gas law. The $\delta^{13} \mathrm{C}$ of emitted $\mathrm{CO}_{2}$ was estimated from the y-axis intercept of derived Keeling plots (Keeling, 1958). The fraction of $\mathrm{CO}_{2}$ derived from grass was calculated using the following equations introduced by Werth and Kuzyakov (2010):

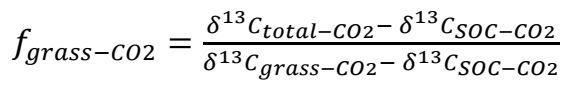

$\delta^{13} C_{\text {grass-CO2 }}=\delta^{13} C_{\text {grass }}-\varepsilon_{\text {grass }}$

$\delta^{13} C_{S O C-C O 2}=\delta^{13} C_{S O C}-\varepsilon_{S O C}$

with $\varepsilon_{\mathrm{SOC}}$ (in \%) the net $\mathrm{C}$-isotopic fractionation resulting from native $\mathrm{SOC}$ mineralization and diffusive $\mathrm{CO}_{2}$ transport in

soil until its efflux into the headspace air. The $\varepsilon_{S O C}$ was obtained from $\mathrm{CO}_{2}$-efflux monitoring parallel triplicate sets of control soils without grass added. A third parallel set of soils were amended with a very high dose of grass (viz. $6 \mathrm{~g} \mathrm{~kg}^{-1}$ added grass, i.e. about $4 \mathrm{t} \mathrm{C} \mathrm{ha-1)}$ to estimate $\varepsilon_{\text {grass. }}$ This value was operationally calculated by subtracting $\delta^{13} C_{\text {grass }}$ from the 
https://doi.org/10.5194/soil-2022-13

Preprint. Discussion started: 24 February 2022

(c) Author(s) 2022. CC BY 4.0 License.

(c) (i)

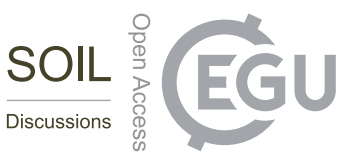

peak $\mathrm{CO}_{2}$ emission $\delta^{13} \mathrm{C}-\mathrm{CO}_{2}$ of soil with $6 \mathrm{~g} \mathrm{~kg}^{-1}$ grass under the assumption that virtually any emitted $\mathrm{CO}_{2}$ was then derived from grass mineralization.

170

Using equations 1, 2 and 3 the fraction of emitted $\mathrm{CO}_{2}$ derived from grass-C mineralization was calculated per soil and per point in time. The rate of grass-C mineralization $\left(C_{\text {grass-min, in }} \mathrm{mg} \mathrm{C} \mathrm{kg}^{-1} \mathrm{~h}^{-1}\right)$ for each measurement day was calculated by multiplying the $f_{\text {grass }}$ value with the total $\mathrm{CO}_{2}$ emission. The rate of SOC mineralization $\left(\mathrm{C}_{\text {Soc }}\right.$ min, in $\left.\mathrm{mg} \mathrm{C} \mathrm{kg}^{-1} \mathrm{~h}^{-1}\right)$ was calculated by subtracting the rate of $C_{\text {grass }}-\mathrm{min}$ from the total $\mathrm{CO}_{2}-\mathrm{C}$ emission rate. Cumulative $\mathrm{CO}_{2}$ emissions derived from native SOC-C and grass-C were obtained by consecutively summing up $C_{\mathrm{SOC}-\mathrm{CO} 2}$ and $C_{\text {grass-CO2 }}$ respectively per time increment between flux measurements. The $\%$ of mineralized $C_{\mathrm{SOC}}$ was then derived from dividing $C_{\mathrm{SOC}-\mathrm{CO} 2}$ by $C_{\mathrm{SOC}}$.

\subsection{Statistics}

Independent samples t-tests were used to compare both land uses (native and pine forest vs. agriculture, or alternatively agriculture vs. pine forests only) for the distribution of OC over soil fractions and for the cumulative amounts of grass-C or native SOC mineralized. Pearson correlation coefficients were used to investigate relations between soil carbon fraction proportions and geochemical properties. The non-parametric test was used if the data were not normally distributed or if the condition of homoscedasticity was unmet. Analyses were completed in IBM SPSS Statistics 27.

\section{Results}

\subsection{Organic carbon in soil fractions}

185 Across the studied soils a greater part of soil material $( \pm 55 \%)$ was found as S+A fraction (Table 2). The highest S+A fraction occurred in the AG1, AG2, and topsoil PF1 soils (> $60 \%$ ). Conversely, in the PF2 and AG3 soils, the s+c fraction was largest. The OC concentration of soil fractions decreased in the order of $\mathrm{POM}>\mathrm{s}+\mathrm{c}$ (including $\mathrm{rSOC}$ ) $>\mathrm{S}+\mathrm{A}>\mathrm{DOC}$ and was generally higher in the topsoil than subsoil. The OC concentration of the S+A fraction was higher under agricultural than under forest land use ( $\mathrm{p}<0.01$ ), particularly in topsoils of AG1 and AG3 (25-55 g C kg${ }^{-1}$ fraction). No such difference in OC concentration existed between SOC in the s+c, POM, DOC and rSOC fractions under agriculture compared to forest (i.e. including primary forest). However, the OC concentration of rSOC fraction was higher $(\mathrm{p}<0.01)$ in the agricultural than pine forests sites. The size of the DOC fraction was negligibly small $\left( \pm 0.002 \mathrm{~g} \mathrm{C} \mathrm{kg}^{-1}\right.$ fraction$)$ and is further disregarded. Total SOC was not significantly different under forest $\left(25.0 \pm 12.4 \mathrm{~g} \mathrm{C} \mathrm{kg}^{-1}\right.$ soil) and agricultural $(30.6 \pm 16.4 \mathrm{~g}$ $\mathrm{C} \mathrm{kg}^{-1}$ soil) land use, but it was higher under agriculture than pine forest $\left(18.4 \pm 8.9 \mathrm{~g} \mathrm{C} \mathrm{kg}^{-1}\right.$ soil $)$.

Overall, the bulk of SOC was present in the S+A $( \pm 47 \%)$ fraction, then followed by the rSOC $( \pm 25 \%), \mathrm{s}+\mathrm{c}-\mathrm{rSOC}( \pm 24$ $\%)$, and POM (<5\%) fractions (Fig. 1). The rSOC constituted 34-67\% of OC in s+c. The distribution of SOC across soil fractions varied to some extent between both land uses. The amount of $\mathrm{OC}$ in the $\mathrm{S}+\mathrm{A}$ fraction was higher in the agricultural 
https://doi.org/10.5194/soil-2022-13

Preprint. Discussion started: 24 February 2022

(c) Author(s) 2022. CC BY 4.0 License.

soils $\left(19 \pm 13 \mathrm{~g} \mathrm{C} \mathrm{kg}^{-1}\right.$ soil) than under forest $\left(8 \pm 4 \mathrm{~g} \mathrm{C} \mathrm{kg}^{-1}\right.$ soil; $\left.\mathrm{p}<0.01\right)$. Particularly in topsoil of AG1 $\left( \pm 23 \mathrm{~g} \mathrm{C} \mathrm{kg}^{-1}\right.$ soil) and AG2 (37 $\mathrm{g} \mathrm{C} \mathrm{kg}^{-1}$ soil) a larger share of the SOC was in the $\mathrm{S}+\mathrm{A}$ fraction. In contrast, more $\mathrm{C}$ was contained in free $\mathrm{POM}$ and in the $\mathrm{s}+\mathrm{c}$ fraction under forest than under agricultural land use $(\mathrm{p}<0.05)$. The resistant SOC (rSOC) fraction accounted for approximately one quarter of SOC and its amount (in $\mathrm{g} \mathrm{C} \mathrm{kg}^{-1}$ soil) and proportion (\% of SOC) was higher under forest than under agricultural land use $(\mathrm{p}<0.05)$. Free POM constituted a significantly larger share of SOC in topsoil compared to both subsoil depth layers ( $\mathrm{p}<0.05$ ), although this pool contributed on average less than $5 \%$ of SOC.

Table 2. Mass proportion, C concentration and total content of SOC contained in soil fractions isolated by the Zimmermann et al. (2007) method

\begin{tabular}{|c|c|c|c|c|c|c|c|c|c|c|c|c|}
\hline \multirow{3}{*}{$\begin{array}{c}\text { Depth } \\
(\mathrm{cm})\end{array}$} & \multicolumn{3}{|c|}{ Mass proportion (\%) } & \multicolumn{5}{|c|}{$\mathrm{C}$ concentration $\left(\mathrm{g} \mathrm{kg}^{-1}\right.$ fraction $)$} & \multicolumn{4}{|c|}{ Amount of $\mathrm{C}$ ( $\mathrm{g} \mathrm{kg}^{-1}$ soil $)$} \\
\hline & \multirow[t]{2}{*}{ POM } & \multirow[t]{2}{*}{$\mathbf{S}+\mathbf{A}$} & \multirow[t]{2}{*}{$\mathbf{s + c}$} & \multirow[t]{2}{*}{ POM } & \multirow[t]{2}{*}{$\mathbf{S}+\mathbf{A}$} & \multicolumn{2}{|c|}{$\mathbf{s + c}$} & \multirow[t]{2}{*}{ DOC } & \multirow[t]{2}{*}{ POM } & \multirow[t]{2}{*}{$\mathbf{S}+\mathbf{A}$} & \multicolumn{2}{|c|}{$\mathbf{s + c}$} \\
\hline & & & & & & $\mathrm{s}+\mathrm{c}-\mathrm{rSOC}$ & rSOC & & & & $s+c-r S O C$ & rSOC \\
\hline \multicolumn{13}{|c|}{ Primary forest (NF) } \\
\hline $0-20$ & $0.3 \pm 0.1$ & $52.8 \pm 0.1$ & $46.9 \pm 0.1$ & $412.5 \pm 33.5$ & $22.6 \pm 6.8$ & $32.2 \pm 3.3$ & $30.5 \pm 3.3$ & $1.0 \pm 0.5$ & $1.4 \pm 0.3$ & $11.9 \pm 3.5$ & $15.1 \pm 1.6$ & $14.3 \pm 1.5$ \\
\hline $20-40$ & $1.7 \pm 0.4$ & $46.7 \pm 3.6$ & $51.6 \pm 3.7$ & $393.0 \pm 0.0$ & $7.5 \pm 2.0$ & $16.9 \pm 2.1$ & $24.9 \pm 2.2$ & $0.7 \pm 0.7$ & $6.6 \pm 1.6$ & $3.6 \pm 1.2$ & $8.7 \pm 1.2$ & $12.9 \pm 1.7$ \\
\hline $60-80$ & $0.2 \pm 0.1$ & $50.0 \pm 10.5$ & $49.8 \pm 10.4$ & $367.5 \pm 88.5$ & $23.9 \pm 5.5$ & $18.8 \pm 3.1$ & $36.3 \pm 1.5$ & $0.8 \pm 0.5$ & $0.8 \pm 0.6$ & $12.1 \pm 4.5$ & $9.5 \pm 3.4$ & $17.9 \pm 3.4$ \\
\hline \multicolumn{13}{|c|}{ Pine forest (PF1) } \\
\hline $0-20$ & $0.7 \pm 0.5$ & $59.0 \pm 11$ & $40.3 \pm 11.5$ & $227.0 \pm 6.0$ & $19.7 \pm 1.7$ & $12.1 \pm 1.0$ & $9.8 \pm 1.0$ & $1.9 \pm 0.5$ & $1.7 \pm 1.2$ & $11.6 \pm 2.0$ & $4.9 \pm 1.6$ & $3.9 \pm 1.2$ \\
\hline $20-40$ & $0.2 \pm 0.1$ & $61.4 \pm 5.6$ & $38.4 \pm 5.8$ & $162.0 \pm 9.5$ & $11.8 \pm 0.2$ & $6.8 \pm 0.3$ & $7.1 \pm 0.3$ & $1.0 \pm 0.4$ & $0.4 \pm 0.2$ & $7.2 \pm 0.7$ & $2.6 \pm 0.4$ & $2.7 \pm 0.4$ \\
\hline $70-90$ & $0.1 \pm 0.1$ & $29.9 \pm 2.5$ & $70.0 \pm 2.6$ & $103.6 \pm 7.5$ & $4.8 \pm 0.1$ & $3.4 \pm 0.1$ & $4.1 \pm 0.2$ & $0.4 \pm 0.2$ & $0.1 \pm 0.07$ & $1.4 \pm 0.1$ & $2.4 \pm 0.0$ & $2.9 \pm 0.3$ \\
\hline
\end{tabular}

Pine forest (PF2)

\begin{tabular}{|c|c|c|c|c|c|c|c|c|c|c|c|c|}
\hline $0-20$ & $1.3 \pm 0.4$ & $46.3 \pm 5.5$ & $52.5 \pm 5.3$ & $188.3 \pm 43.2$ & $26.7 \pm 2.5$ & $19.6 \pm 1.8$ & $17.6 \pm 1.3$ & $1.7 \pm 0.6$ & $2.2 \pm 0.2$ & $12.4 \pm 2.6$ & $10.4 \pm 1.9$ & $9.2 \pm 0.8$ \\
\hline $0-40$ & $0.4 \pm 0.1$ & $45.2 \pm 5.6$ & $54.3 \pm 5.6$ & $148.7 \pm 47.3$ & $14.3 \pm 0.7$ & $10.4 \pm 0.1$ & $10.4 \pm 0.1$ & $1.5 \pm 0.4$ & $0.6 \pm 0.1$ & $6.5 \pm 1.1$ & $5.7 \pm 0.6$ & $5.7 \pm 0.5$ \\
\hline $0-80$ & $0.2 \pm 0.1$ & $36.1 \pm 4.7$ & $63.7 \pm 4.8$ & $135.6 \pm 48.9$ & $16.0 \pm 12.1$ & $7.7 \pm 0.7$ & $8.0 \pm 0.3$ & $1.1 \pm 0.0$ & $0.2 \pm 0.1$ & $5.7 \pm 4.3$ & $5.0 \pm 0.8$ & $5.1 \pm 0.2$ \\
\hline \multicolumn{13}{|c|}{ Agriculture (AG1) } \\
\hline $0-20$ & $0.1 \pm 0.1$ & $74.8 \pm 6.7$ & $25.1 \pm 6.7$ & $206.0 \pm 4.0$ & $31.3 \pm 0.9$ & $12.8 \pm 0.2$ & $17.8 \pm 0.1$ & $1.5 \pm 0.9$ & $0.2 \pm 0.1$ & $23.4 \pm 1.6$ & $3.2 \pm 0.1$ & $4.4 \pm 1.1$ \\
\hline $0-40$ & $0.1 \pm 0.0$ & $72.3 \pm 2.8$ & $27.7 \pm 2.9$ & $63.7 \pm 0.9$ & $14.8 \pm 0.3$ & $6.6 \pm 0.4$ & $9.5 \pm 0.3$ & $0.3 \pm 0.1$ & $0.03 \pm 0.0$ & $10.7 \pm 0.2$ & $1.8 \pm 0.1$ & $2.6 \pm 0.3$ \\
\hline $60-80$ & $0.1 \pm 0.0$ & $72.2 \pm 3.3$ & $27.7 \pm 3.3$ & $15.6 \pm 2.4$ & $12.2 \pm 0.2$ & $5.5 \pm 0.1$ & $7.6 \pm 0.2$ & $0.4 \pm 0.1$ & $0.01 \pm 0.0$ & $8.8 \pm 0.3$ & $1.5 \pm 0.2$ & $2.1 \pm 0.2$ \\
\hline
\end{tabular}

Agriculture (AG2)

$0-20 \quad 0.1 \pm 0.1 \quad 68.8 \pm 1.6 \quad 31.3 \pm 1.6 \quad 350.0 \pm 52.0 \quad 54.1 \pm 1.6$

$28.5 \pm 3.436 .1 \pm 3.2 \quad 0.6 \pm 0.1 \quad 0.3 \pm 0.2 \quad 37.2 \pm 1.6 \quad 8.9 \pm 1.3 \quad 11.3 \pm 1.0$

$20-40 \quad 0.0 \pm 0.0 \quad 85.9 \pm 0.8 \quad 14.1 \pm 0.8 \quad 401.0 \pm 88.0 \quad 46.5 \pm 0.4$

$16.4 \pm 2.4 \quad 31.4 \pm 1.8 \quad 1.1 \pm 0.7 \quad 0.04 \pm 0.0 \quad 40 \pm 0.1 \quad 2.3 \pm 0.2 \quad 4.4 \pm 0.5$

$50-70 \quad 0.0 \pm 0.0 \quad 85.3 \pm 1.2 \quad 14.7 \pm 1.2 \quad 587.5 \pm 240 \quad 28.3 \pm 0.3$

$10.7 \pm 1.3 \quad 19.7 \pm 0.7 \quad 0.8 \pm 0.4 \quad 0.08 \pm 0.0 \quad 24.2 \pm 0.4 \quad 1.6 \pm 0.1 \quad 2.9 \pm 0.3$

Agriculture (AG3)

$0-20 \quad 0.7 \pm 0.1 \quad 34.4 \pm 6.7 \quad 64.9 \pm 6.7 \quad 420.7 \pm 88.3 \quad 38.3 \pm 4.6$

$29.8 \pm 1.917 .2 \pm 0.8 \quad 1.8 \pm 0.4 \quad 2.9 \pm 0.6 \quad 13.1 \pm 2.5 \quad 19.5 \pm 3.2 \quad 11.1 \pm 1.0$

$20-40 \quad 0.8 \pm 0.2 \quad 42.3 \pm 8.7 \quad 56.9 \pm 8.7 \quad 311.3 \pm 39.9 \quad 23.0 \pm 0.4$

$16.7 \pm 0.7 \quad 12.5 \pm 1.1 \quad 1.3 \pm 0.4 \quad 2.4 \pm 0.3 \quad 9.7 \pm 1.8 \quad 9.6 \pm 1.7 \quad 7.1 \pm 0.6$ 
https://doi.org/10.5194/soil-2022-13

Preprint. Discussion started: 24 February 2022

(c) Author(s) 2022. CC BY 4.0 License.

(c) (i)

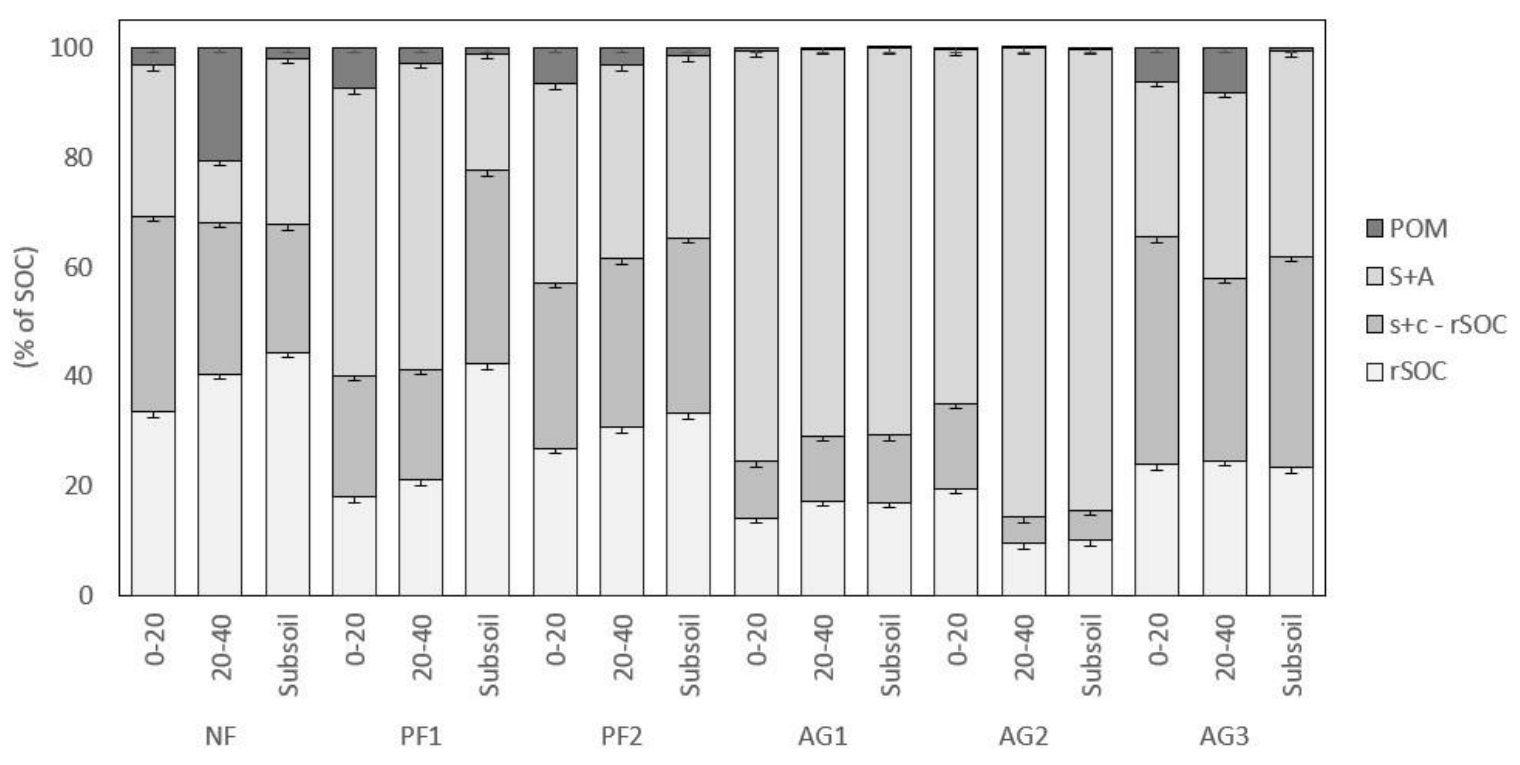

210 Figure 1. The distribution of $\mathrm{OC}$ over soil fractions obtained by the Zimmerman et al. (2007) procedure for 6 sampled (0-60cm) soil profiles in the Sunda Volcanic complex in West Java, Indonesia. Vertical bars indicate standard deviations for three labreplicates $(\mathbf{n}=\mathbf{3})$

\subsection{Correlations between SOC fractions and selected chemical soil properties}

The proportion of several of the isolated SOC fractions correlated to some of the geochemical soil properties (Fig.2). Across

215 all land uses and depths, the $\mathrm{SOC}$ proportion of the $\mathrm{S}+\mathrm{A}$ fraction was positively correlated with $\mathrm{Al}_{\mathrm{o}}, \mathrm{Al}_{\mathrm{o}}+1 / 2 \mathrm{Fe}_{\mathrm{o}}, \mathrm{pH} \mathrm{H}_{2} \mathrm{O}$, exchangeable $\mathrm{Ca}$, and content of amorphous materials $(\mathrm{p}<0.01)$. These soil properties were also positively correlated with the amount of $\mathrm{OC}$ in $\mathrm{S}+\mathrm{A}$ fraction $\left(\mathrm{g} \mathrm{C} \mathrm{kg}^{-1}\right.$ soil) and $\mathrm{OC}$ concentration in $\mathrm{S}+\mathrm{A}$ fraction $\left(\mathrm{g} \mathrm{C} \mathrm{kg}^{-1}\right.$ fraction). There existed no significant correlations between the proportion of the other SOC fractions and any of the analyzed soil properties for the full dataset. But when considering only pine forest and agriculture, positive correlations existed between OC concentrations of the $\mathrm{s}+\mathrm{c}$ and $\mathrm{rSOC}$ fractions $\left(\mathrm{g} \mathrm{C} \mathrm{kg}^{-1}\right.$ fraction) with $\mathrm{Al}_{\mathrm{o}}$ and $\mathrm{Al}_{\mathrm{o}}+1 / 2 \mathrm{Fe}_{\mathrm{o}}$. 

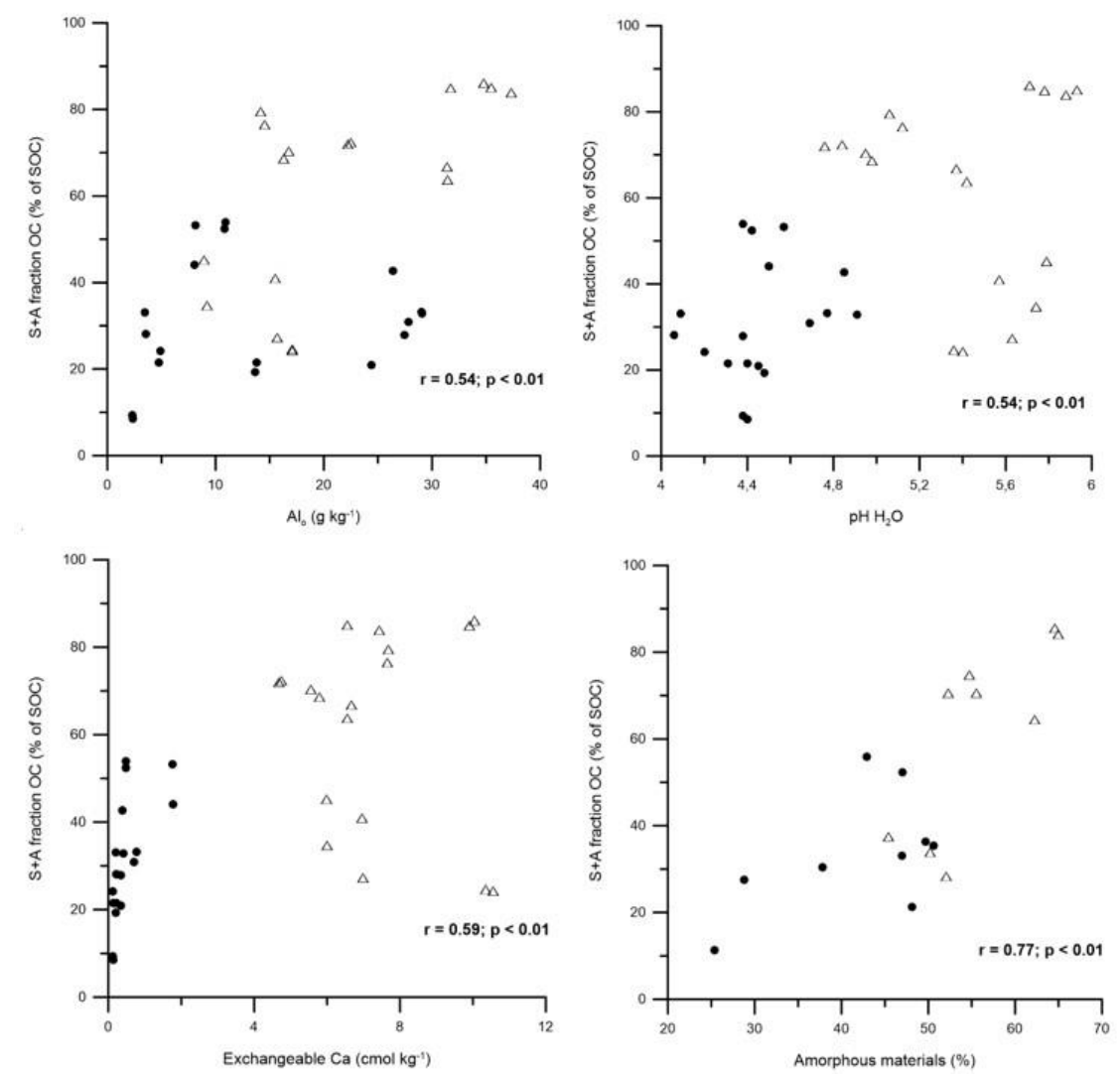

Figure 2. Scatter plots of the SOC proportion of the S+A fraction and selected chemical soil properties, with Pearson correlation coefficients and corresponding statistical significance level indicated. Sites under agriculture and forest are indicated by $\Delta$ and $\bullet$ respectively.

\subsection{Carbon mineralization experiment}

\subsubsection{Gross soil carbon mineralization}

Across all sites, C-mineralization (C-min) rates were highest for AG2 and AG3 and peaked already during the first day of incubation, while for the other soils rates peaked at day 3 or 5 only. After day 38, the C-min rates stabilized across time. The cumulative total $\mathrm{CO}_{2}-\mathrm{C}$ emission and derived amount of $\mathrm{C}$-mineralized ( $\mathrm{SOC}+$ ryegrass) generally followed a sequence $\mathrm{NF}$

$230<\mathrm{AG} 1<\mathrm{AG} 2<\mathrm{PF} 1<\mathrm{AG} 3<\mathrm{PF}$. Pine forest soils displayed higher cumulative $\mathrm{C}$ mineralization than agricultural soils ( $\mathrm{p}$ $<0.05$ ). Overall, 120-day cumulative $\mathrm{C}$ mineralization was $194-419 \mathrm{mg} \mathrm{kg}^{-1}$ higher in soil with grass added than without (Fig. 3). 
https://doi.org/10.5194/soil-2022-13

Preprint. Discussion started: 24 February 2022

(c) Author(s) 2022. CC BY 4.0 License.

(c) (i)

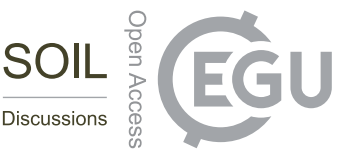

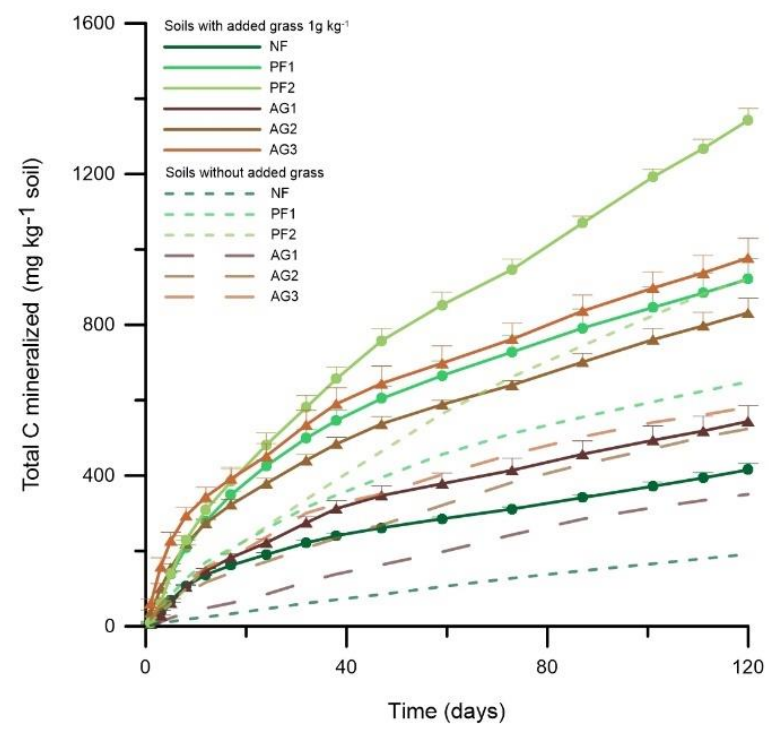

Figure 3. Gross cumulative amount of $\mathrm{C}$ mineralized in soil with and without $1 \mathrm{~g} \mathrm{C} \mathrm{kg}^{-1}$ ryegrass added. Vertical bars indicate 235 standard deviations of three lab replicates $(n=3)$ and are presented for the grass amended soils only. Sites under forest and agriculture are indicated by $\bullet$ and $\Delta$, respectively.

\subsubsection{Grass C-mineralization}

The $C_{\text {grass }}$-min rates peaked within 12 days after the start of the incubation, and they dropped thereafter to just half to one third of the initial rates. The $\mathrm{C}_{\text {grass }}$ mineralization rate was conspicuously high on the first day of incubation in soils AG2 and

240 AG3, whereas for the other soils mineralization peaked on day 5 only. From day 38 onwards, the $C_{\text {grass }}$-min rate had become more or less similar in all six sites. By the end of the 120-days incubations, 22-38\% of the added ryegrass had been mineralized. The highest cumulative $C_{\text {grass }}-$ min was found for PF2 $\left(389 \mathrm{mg} \mathrm{kg}^{-1}\right)$, followed by AG2 $>$ AG3 $\approx \mathrm{PF} 1 \approx \mathrm{AG} 1>$ NF. There were no significant differences in $C_{\text {grass }}-$ min between the sets of agricultural and forest soils. 

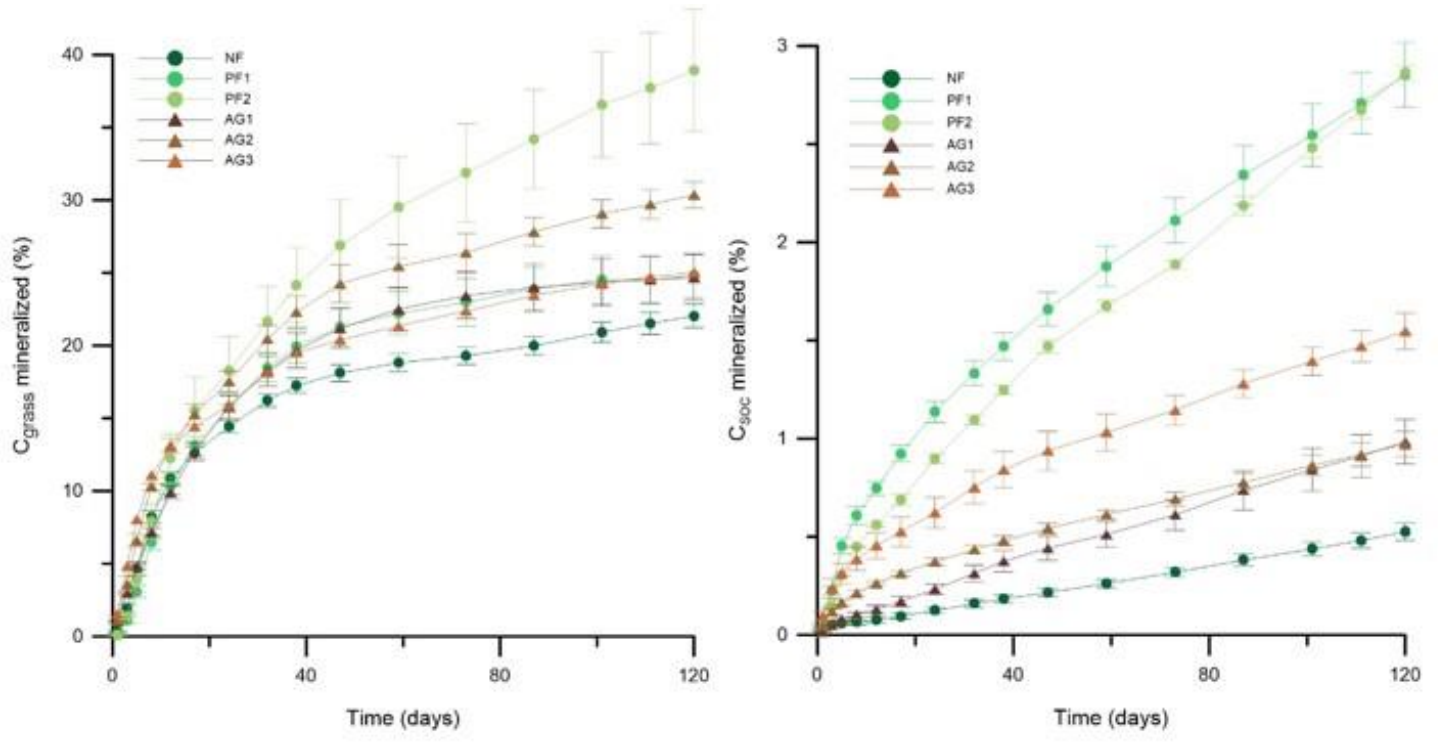

245 Figure 4. The percentage of $C_{\text {grass }}\left(\right.$ left) and $C_{\text {SOC }}$ (right) mineralized during 120 days of incubation in soils with $1 \mathrm{~g} \mathrm{~kg}^{-1} \mathrm{grass}$ or no grass added, respectively. Vertical bars indicate standard deviations of triplicate lab repetitions. Sites under forest and agriculture are indicated by $\bullet$ and $\Delta$, respectively.

\subsubsection{Native SOC C-mineralization}

Mineralization of SOC $\left(C_{\mathrm{SOC}}-\mathrm{min}\right)$ contributed more to gross soil $\mathrm{C}$ mineralization than $\mathrm{C}_{\text {grass }}-\mathrm{min}$ did. There were large differences in $C_{\mathrm{SOC}}$-min between the 0-20 cm soil layers of the six sites. By the end of the incubation, the highest cumulative amount of SOC mineralized was found for PF2 $\left(953 \pm 13 \mathrm{mg} \mathrm{kg}^{-1}\right)$ while a fourfold lower amount was mineralized in case of $\mathrm{NF}\left(195 \pm 17 \mathrm{mg} \mathrm{kg}^{-1}\right)$. Significantly less SOC was mineralized in the agricultural soils $\left(517 \pm 90 \mathrm{mg} \mathrm{kg}^{-1}\right)$ than in the pine forest soils $\left(813 \pm 156 \mathrm{mg} \mathrm{kg}^{-1}\right)(\mathrm{p}<0.01)$. Relatively $0.5-2.9 \%$ of the SOC had been mineralized within the 120 days incubations (Fig. 4). A larger \% of SOC was mineralized in the pine forest soils $(2.9 \% \pm 0.1)$ than in the agricultural soils $(1.2 \% \pm 0.3)(\mathrm{p}<0.01)$.

Priming of native SOC mineralization was assessed by comparing $C_{\mathrm{SOC}}-\mathrm{min}$ between the soils with and without $1 \mathrm{~g} \mathrm{~kg}^{-1}$ grass added (Fig. 5). During the first week, grass addition tended to increase the $\mathrm{C}_{\text {soc-min }}$ rate in most soils, i.e. there was positive priming of native SOC. Along the 120-days experiment, however, the direction and magnitude of the net cumulative priming effect varied strongly among soils. Little or no net priming of $C_{\mathrm{SOC}}$-min occurred in the NF soil, as a result of initial positive priming until day 17 but negative priming afterwards. In the pine forest soils likewise periods of positive and negative priming alternated, with at the end of the 120-days period an alike limited net positive priming of SOC at both PF sites. Priming of SOC was diverse among the three agricultural soils. While strong positive priming throughout the 120-days period in the AG3 soil, while the opposite was true for AG1 and no net priming occurred in case of AG2. On average, the net 120-days cumulative priming of SOC in forest (19.3 mg CO $\left.2-\mathrm{C} \mathrm{kg}^{-1} \mathrm{day}^{-1}\right)$ was lower than agricultural (31.2 $\mathrm{mg} \mathrm{CO}_{2}-\mathrm{C} \mathrm{kg}^{-1}$ 
https://doi.org/10.5194/soil-2022-13

Preprint. Discussion started: 24 February 2022

(c) Author(s) 2022. CC BY 4.0 License.

(c) (i)

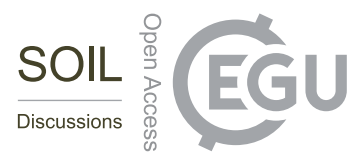

day $^{-1}$ ) land use, but due to wide variation between replicate sites this difference proved insignificant and moreover net priming rates were not significantly different from zero.

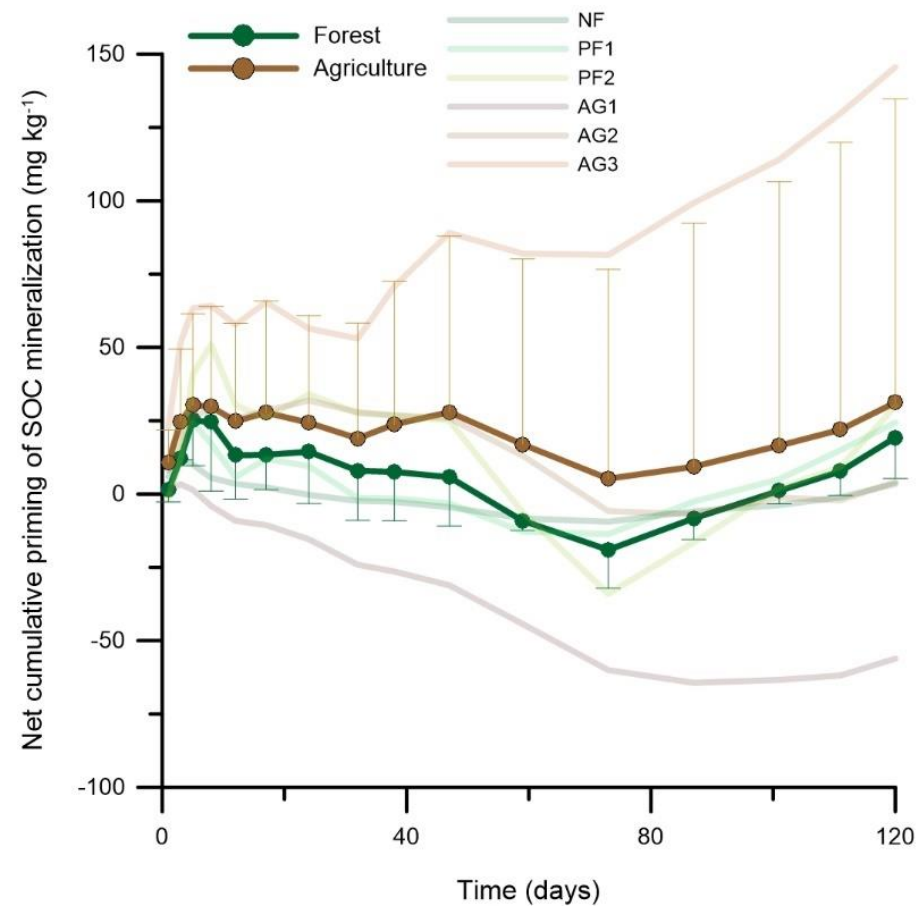

Figure 5. Net effect of grass addition $\left(1 \mathrm{~g} \mathrm{~kg}^{-1}\right)$ on cumulative native SOC mineralization. Positive and negative figures denote net positive or net negative cumulative priming of SOC mineralization. Dotted lines present the temporal evolution of mean net cumulative priming effect for either forest or agricultural land use, with respectively only upper or lower error bars representing the standard deviations on the data

\section{Discussion}

\subsection{Land use effects on free and aggregate protected OC}

Overall, the portion of S+A fraction material (i.e. $>63 \mu \mathrm{m}$ aggregates and sand particles) was higher in the agricultural $(64 \pm$ $20 \%)$ than forest sites $(48 \pm 11 \%)(\mathrm{p}<0.05)$, indicating stronger soil aggregation under agriculture. In line, even a double share of SOC resided in the S+A fraction under agriculture $(61 \pm 21 \%)$ than forest $(34 \pm 15 \%)(\mathrm{p}<0.05)$. The important role of soil microaggregates for SOC storage has been displayed by numerous studies (Dungait et al., 2012; Rabbi et al., 2016; Six et al., 2002). We expected a lesser share of SOC to be occluded inside aggregates in the tilled agricultural soils, as absence of tillage results in less disruption of macroaggregates with increased formation of microaggregates and occlusion of POM (Six et al., 2000b; Zheng et al., 2018). However, tillage is not the only determinant of soil aggregate formation and breakdown, aggregate stability also depends on presence of binding agents that cluster mineral and organic particles into aggregates. Repeated addition of labile $\mathrm{C}$ via manure and compost amendments was shown to result in greater formation of macroaggregate (Du et al., 2014; Mikha and Rice, 2004; Yu et al., 2012) by increased production of microbial-derived 
https://doi.org/10.5194/soil-2022-13

Preprint. Discussion started: 24 February 2022

(C) Author(s) 2022. CC BY 4.0 License.

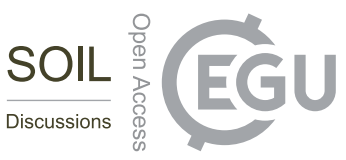

binding agents. Manure and compost amendments to the AG sites were vast (Table 1), and so the enhanced addition of labile $\mathrm{C}$ as compared to the forest sites may have boosted aggregate formation with more SOC storage in the S+A fraction under agricultural land use. Next to organic binding agents, Wagai et al. (2018) also found reactive metal phases to be important binding agents in Allophanic Andisols. With high to very high levels of $\mathrm{Al}_{\mathrm{o}}$ (up to $4 \%$ of the soil mass), it seems very likely that amorphous to poorly crystalline Al-containing minerals would have been prominent binding agents in our set of soils. The SOC proportion of the S+A fraction and its OC concentration $\left(\mathrm{g} \mathrm{C} \mathrm{kg}^{-1} \mathrm{~S}+\mathrm{A}\right.$ fraction) correlated positively with contents of $\mathrm{Al}_{\mathrm{o}}$ and $\mathrm{Al}_{\mathrm{o}}+1 / 2 \mathrm{Fe}_{\mathrm{o}}$, and with the \% of $\mathrm{X}$-ray amorphous materials. This indicates that higher levels of $\mathrm{Al}_{\mathrm{o}}$ under agriculture than forest would have enhanced aggregation, and in doing so occluded a larger share of SOC inside these aggregates. Other than aluminium oxides, the content of exchangeable $\mathrm{Ca}$ also correlated positively to $\mathrm{S}+\mathrm{A}$ fraction mass proportion $(r=0.45)$ and SOC proportion of the $S+A$ fraction $(r=0.59)(p<0.01)$. Soil Ca is also well known for its positive effects on aggregation via formation of clay-polyvalent cation-OM complexes (de Kerchove and Elimelech, 2007; Six et al., 2004). This mechanism might have co-promoted aggregate occlusion of OC and its accumulation (Bertrand et al., 2007; Paul et al., 2003), but given the high $\mathrm{Al}_{\mathrm{o}}$ levels, likely $\mathrm{Ca}^{2+}$ would have played a smaller role. The higher levels of exchangeable $\mathrm{Ca}$ under agriculture compared to forest $(\mathrm{p}<0.05)$ evidently result from liming which increases the $\mathrm{pH}$, thus having higher capacity to bind $\mathrm{Ca}^{2+}$. The concomitant difference in $\mathrm{Al}_{\mathrm{o}}$, exchangeable $\mathrm{Ca}^{2+}$ and $\mathrm{S}+\mathrm{A}$ OC content between agricultural and forest sites makes it impossible to derive the relative importance of these various binding agents in stimulation of aggregate OC occlusion under agricultural land use. Lastly, less free POM was found in the agricultural than forest soils $(\mathrm{p}<0.05)$, likely as a logical consequence of more POM occlusion under agriculture. However, we cannot exclude that also a better degradability of crop-derived residues vs. pine or native forest litter co-explains these trends. It is well established that litter rich in cutin, waxes and lignin such as derived from pine forests is less degradable than plant litter richer in carbohydrates and organic N like most crop residues (Berg and McClaugherty, 2014).

\subsection{Effect of land use on SOC in the silt and clay fraction}

Interaction of SOC with silt and clay provides long-term stabilization to SOC against decomposition and therefore forms a key mechanism for SOC sequestration (De Clercq et al., 2015). SOC sorbs to phyllosilicate clays, Al-, Fe- and Mn-oxides, poorly crystalline minerals, as well as polyvalent cations that form a bridge between minerals and organic constituents (Blanco-Canqui and $\mathrm{Lal}, 2004$ ). However, for our soils we found that despite higher concentrations of $\mathrm{Al}_{\mathrm{o}}$ under agriculture, a lesser share of the SOC was present in the $\mathrm{s}+\mathrm{c}$ fraction (as \% of SOC) compared to the forest soils ( $\mathrm{p}<0.05)$. The content of $\mathrm{s}+\mathrm{c}$ OC (in $\mathrm{g} \mathrm{C} \mathrm{kg}^{-1}$ soil) displayed likewise trends. Particularly, the all-depth layers at the NF site had high s+c content and proportion of SOC, but this was in fact accompanied with a larger contribution of younger less-weathered minerals present, low $\mathrm{Al}_{\mathrm{o}}$ level and smaller share of amorphous minerals (Anindita et al., under review). Hence association of OC

315 with $\mathrm{Al}_{0}$-containing minerals could not explain the higher SOC proportion and amount of OC in $\mathrm{s}+\mathrm{c}$ under forest. Most likely a larger $\mathrm{s}+\mathrm{c}$ proportion of SOC under forest simply mirrors trends in the S+A fraction, although it cannot be ruled out that other factors such as a lower soil nutrient availability, lower soil $\mathrm{pH}$, and likely wetter microclimate and more 
https://doi.org/10.5194/soil-2022-13

Preprint. Discussion started: 24 February 2022

(c) Author(s) 2022. CC BY 4.0 License.

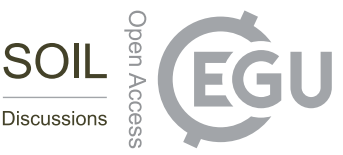

biochemically inert $\mathrm{OC}$ inputs would have caused relative storage of $\mathrm{OC}$ in the $\mathrm{s}+\mathrm{c}$ fraction under forest. Our experimental design did not allow to infer unambiguously if such soil and environmental factors alternatively caused the larger SOC proportions in s+c. Significant positive correlations existed between the share of s+c OC that was oxidizable by $6 \% \mathrm{NaOCl}$ (i.e. $\mathrm{rSOC} / \mathrm{s}+\mathrm{c} \times 100$ ) with content of $\mathrm{Al}_{\mathrm{o}}, \%$ of amorphous materials and the SSA, especially in subsoils where such correlations were strong (Fig. 6). Association of SOC with Fe and $\mathrm{Al}$ (hydr)oxides has indeed before been confirmed to limit oxidation of SOC by $6 \% \mathrm{NaOCl}$ (Mikutta et al., 2006). Since we also found that agricultural land use had higher $\mathrm{Al}_{\mathrm{o}}$ by $14 \%$ compared to pine forest (Table 1), these results at first sight might suggest that the enhanced mineral weathering under agricultural land use lowered the chemical oxidizability of s+c OC. However, the difference in the chemical inertness of the $\mathrm{s}+\mathrm{c}$ OC appeared insignificant between both land uses (agriculture: $53 \%$ of $\mathrm{s}+\mathrm{c}$ vs. pine forest: $49 \% \mathrm{of} \mathrm{s}+\mathrm{c}$ ). This outcome then at least contradicts that more $\mathrm{s}+\mathrm{c} \mathrm{OC}$ would accumulate under forest because of a more biochemical inertness of the OC inputs compared to agriculture.
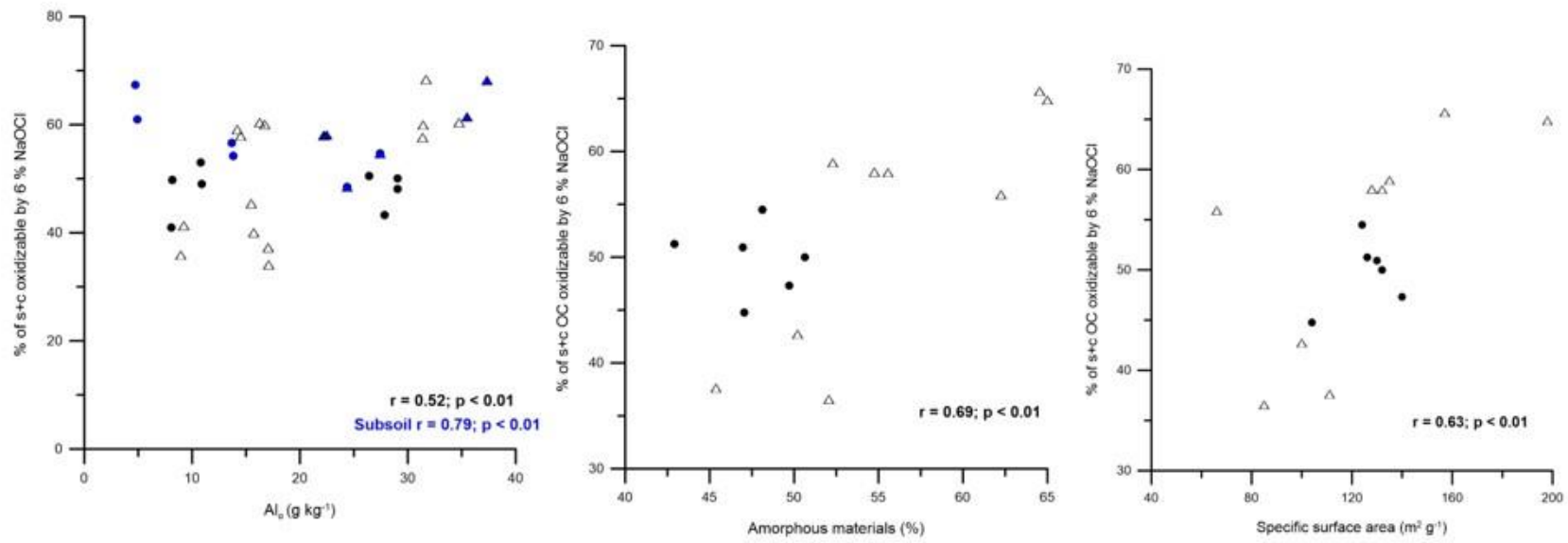

Figure. 6 Relation between the proportion of $\mathrm{rSOC}_{\text {of }}$ the $\mathrm{s}+\mathrm{c}$ fraction in the pine forest and agricultural soils with the soil $\mathrm{Al}_{\mathrm{o}}$ (all dots jointly, $n=30$ ) and for the set of subsoil observations (in blue) specifically; and likewise relations with the \% of amorphous materials, and the soil specific surface area $(n=15, \mathrm{SSA}$ and X-ray diffraction not replicated). Sites under agriculture and pine forest are indicated by $\Delta$ and $\bullet$, respectively. Pearson correlation coefficients in black and blue represent correlations for the total dataset and for the set of subsoils, respectively.

\subsection{Land use effects on native SOC degradability}

The percentage of SOC mineralized after 120 days of incubation was less than half in the agricultural soils (1.2\%) than in the pine forest soils $(2.9 \%)(\mathrm{p}<0.01)$. This result was rather unexpected given the lower soil $\mathrm{pH}$ by 0.8 under pine forest, as acidic conditions are well known to retard SOC decomposition of SOC (Högberg et al., 2007; Malik et al., 2018) in line with Anda and Dahlgren (2020). To understand the apparent relative stabilization of SOC in the agricultural soils, we considered distribution of SOC across soil fractions. We (Anindita et al., under review) previously hypothesized that the nearly doubled $\mathrm{Al}_{\mathrm{o}}$ content of the agricultural soils $\left(21.8 \mathrm{~g} \mathrm{~kg}^{-1}\right.$ on average) compared to the pine forest soils $\left(13.9 \mathrm{~g} \mathrm{~kg}^{-1}\right)$ would explain relatively elevated SOC stocks under agriculture for our study area due to enhanced organo-mineral association. Basile- 
https://doi.org/10.5194/soil-2022-13

Preprint. Discussion started: 24 February 2022

(C) Author(s) 2022. CC BY 4.0 License.

(c) (i)

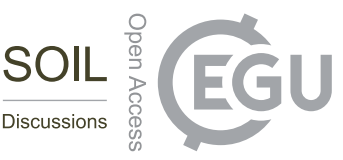

Doelsch et al. (2005) likewise found that volcanic ash soil horizons containing much poorly crystalline material (protoimogolite and proto-imogolite allophane) store large amounts of organic matter which turns over very slowly. But as no negative correlations existed between the amount or proportion of SOC mineralized and $\mathrm{Al}_{\mathrm{o}}$ content, this hypothesis was not confirmed. As mentioned above, we did find a higher $\%$ of SOC to be present in the rSOC fraction under forest but again no correlation existed with SOC mineralization. Mikutta et al. (2006) indeed demonstrated that a larger chemical recalcitrance of SOC does not really translate into a larger biological lability. Moreover, the share of SOC in rSOC was actually lower (but not significantly) under forest than under agriculture and so as argued above, the larger SOC proportion of rSOC seems to simply result from less accumulation of SOC in the S+A fraction under forest.

The proportion and concentration of the $\mathrm{S}+\mathrm{A}$ fraction $\mathrm{OC}$ were higher under agriculture, so enhanced soil aggregation and occlusion of SOC might have significantly physically protected SOC against microbially mediated decomposition compared to pine forest land use. A study of Andosols in Colombia by Gijsman and Sanz (1998) also reported that aggregation holds considerable control on SOC decomposability as these authors observed a significant increase of $\mathrm{CO}_{2}$ mineralization after crushing large and small macroaggregates (> $53 \mu \mathrm{m})$. Indeed, we found that the amount of OC $\left(\mathrm{g} \mathrm{C} \mathrm{kg}^{-1}\right.$ soil) in the S+A fraction negatively correlated to $\%$ SOC mineralized for the set of soils with agricultural and pine forest land use $(r=-0.75$; $\mathrm{p}<0.01)$. It then appears that enhanced soil aggregation and occlusion of SOC under agricultural land use in part limited degradability of SOC, rather than enhanced association of SOC with soil minerals, including poorly crystalline or amorphous Al-containing minerals. Formation of amorphous materials and $\mathrm{Al}_{\mathrm{o}}$ in the agricultural soils most likely promoted soil aggregation. Hence, we provisionally conclude that enhanced pedogenesis forms a relevant indirect mechanism via which conversion to agricultural land use impacts the SOC balance of these relatively young tropical volcanic soils.

\subsection{Land use effects of exogenous organic matter decomposition and net priming of SOC}

In contrast to native SOC mineralization, added grass $\mathrm{C}$ mineralization did not differ between forest and agricultural soils.

365 Therefore, apparently protection of ryegrass OC either by mineral association or occlusion inside aggregates must have been similar between both land uses and, in any case, did not impact its degradability in soil. Laboratory incubations with disturbed soils do not necessarily adequately reproduce field conditions in terms of soil structure, microclimate, and food webs. The observed similar degradability of ryegrass-C does not suggest a likewise enhanced storage of freshly added OM like for native SOC under agriculture than under forest. Possibly, such impact only emerges on the longer term when the added OM has been subject to sufficient diminution into smaller POM that could be occluded in microaggregates. Six et al. (2002) summarized that particularly 50-250 $\mu \mathrm{m}$ scaled microaggregates grant sizable physical protection to POM, while the macroaggregate $(>250 \mu \mathrm{m}$ ) structure exerts little control on POM decomposability. Adding ryegrass to the $0-20 \mathrm{~cm}$ soils initially seemed to impact mineralization of native SOC with a general positive priming effect in first week of incubation, in line with many other studies, e.g. Liu et al. (2017). Thereafter, however, in four of the six studied soils net negative priming countered this initial stimulation of SOC mineralization. Such adverse impact of adding fresh OM on SOC mineralization 
could be due to a preferential utilization of the added substrate by microorganisms (Derrien et al., 2014). Regardless, the net result was that after 120 days SOC mineralization was not significantly stimulated (on average by $1.6 \%$ ). There was also no land use effect on the net priming of SOC after 120 days. Hence, in spite of differences in SOC quality under both land uses, as inferred from different SOC proportions of S+A and free POM, no differential stimulation of SOC mineralization by addition of a relatively labile plant-C substrate existed between agricultural or forest land use. These observations imply that no adverse effect is to be expected of the addition of generally relatively labile C (above ground crop residues, animal manure) on stability of the native SOC present under agricultural land use.

\section{Conclusions}

Following the fractionation of SOC by Zimmermann et al., (2007), the sand-aggregates fraction in general was a dominant 385 SOC pool in our soils, accounting for $47 \%$ of total $\mathrm{SOC}$ in all soil fractions, and was positively associated to $\mathrm{Al}_{\mathrm{o}}$, $\mathrm{Al}_{\mathrm{o}}+1 / 2 \mathrm{Fe}_{\mathrm{o}}$, exchangeable $\mathrm{Ca}, \mathrm{pH}$, and amorphous materials. Our study thus indicates that higher levels of poorly crystalline $\mathrm{Al}$, more amorphous materials and under agricultural land use stimulate soil aggregation and physical occlusion of OC compared to forest land use. The negative correlation between the portion of SOC that is physically occluded on the one hand and to lower relative decomposability of the SOC on the other, suggest that enhanced soil aggregation under cropland indeed effectively stabilizes part of the SOC compared to under forest land use. Contrary to our hypothesis we found no proof that stimulated formation of $\mathrm{Al}_{\mathrm{o}}$ and amorphous minerals would have increased association of SOC with soil minerals under agriculture. Based on the present study we do postulate that faster pedogenesis under agriculture would counter otherwise expected loss of SOC compared to secondary forest, but further study of more tropical Andosol land use pairs with detailed inventory of OC inputs is now needed to affirm this. To the least, our study points at the overall need to account for potential indirect land use effects on stability of SOC via its control on pedogenesis. Especially, this is so for pedoclimatic combinations where weathering can be very fast, like in tropical Andosols that have relatively recently been cultivated.

\section{Appendix}

No Appendix

\section{Data availability}

400 The data generated in this study are available from the corresponding author upon reasonable request 
https://doi.org/10.5194/soil-2022-13

Preprint. Discussion started: 24 February 2022

(c) Author(s) 2022. CC BY 4.0 License.

(c) (i)

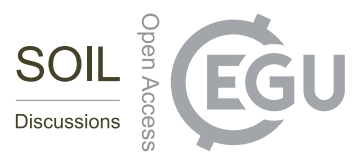

\section{Author contributions}

SS, PF, and SA conceptualized the study. SA conducted soil sampling and performed the experiment. SA prepared the manuscript with contributions from all the co-authors.

\section{Competing interest}

405 The authors declare that they have no conflict of interest

\section{Acknowledgments}

We thank Indonesia Endowment Fund for Education (LPDP) for the internal support of this research, Orly Mendoza, Haichao Li, and Heleen Dero from Soil Fertility Research Group (Ghent University) for laboratory assistance.

\section{Financial support}

410 This research has been supported by Indonesia Endowment Fund for Education (LPDP).

\section{References}

Anda, M. and Dahlgren, R. A.: Long-term response of tropical Andisol properties to conversion from rainforest to agriculture, Catena, 194, 104679, doi:10.1016/j.catena.2020.104679, 2020.

Anindita, S., Sleutel, S., Vandenberghe, D., De Grave, J., Vandenhende, V. and Finke, P.: Land use impacts on weathering

415 and carbon sequestration in Sunda-Tangkuban Perahu volcanic region, Indonesia, "in review". (likely to be published during the review process of this article).

Asano, M. and Wagai, R.: Evidence of aggregate hierarchy at micro- to submicron scales in an allophanic andisol, Geoderma, 216, 62-74, doi:10.1016/j.geoderma.2013.10.005, 2014.

Asano, M. and Wagai, R.: Distinctive organic matter pools among particle-size fractions detected by solid-state 13C-NMR,

$420 \delta 13 \mathrm{C}$ and $\delta 15 \mathrm{~N}$ analyses only after strong dispersion in an allophanic andisol, Soil Sci. Plant Nutr., 61(2), 242-248, doi:10.1080/00380768.2014.982492, 2015.

Asano, M., Wagai, R., Yamaguchi, N., Takeichi, Y., Maeda, M., Suga, H. and Takahashi, Y.: In Search of a Binding Agent:

Nano-Scale Evidence of Preferential Carbon Associations with Poorly-Crystalline Mineral Phases in Physically-Stable, Clay-Sized Aggregates, Soil Syst., 2(2), 32, doi:10.3390/soilsystems2020032, 2018.

425 Baldock, J. A.: Composition and Cycling of Organic Carbon in Soil, in Nutrient Cycling in Terrestrial Ecosystems, edited by P. Marschner and Z. Rengel, pp. 1-35, Springer Berlin, Heidelberg., 2007. 
https://doi.org/10.5194/soil-2022-13

Preprint. Discussion started: 24 February 2022

(c) Author(s) 2022. CC BY 4.0 License.

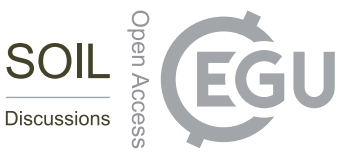

Bartoli, F., Burtin, G. and Herbillon, A. J.: Disaggregation and clay dispersion of Oxisols: Na resin, a recommended methodology, Geoderma, 49(3-4), 301-317, doi:10.1016/0016-7061(91)90082-5, 1991.

Basile-Doelsch, I., Amundson, R., Stone, W. E. E., Borschneck, D., Bottero, J. Y., Moustier, S., Masin, F. and Colin, F.:

Mineral control of carbon pools in a volcanic soil horizon, Geoderma, 137(3-4), 477-489, doi:10.1016/j.geoderma.2006.10.006, 2007.

Berg, B. and McClaugherty, C.: Plant litter: decomposition, humus formation, carbon sequestration, Third., Springer Berlin Heidelberg, New York., 2014.

Bertrand, I., Delfosse, O. and Mary, B.: Carbon and nitrogen mineralization in acidic, limed and calcareous agricultural soils: Apparent and actual effects, Soil Biol. Biochem., 39(1), 276-288, doi:10.1016/j.soilbio.2006.07.016, 2007.

Blagodatskaya, E., Khomyakov, N., Myachina, O., Bogomolova, I., Blagodatsky, S. and Kuzyakov, Y.: Microbial interactions affect sources of priming induced by cellulose, Soil Biol. Biochem., 74, 39-49, doi:10.1016/j.soilbio.2014.02.017, 2014.

Blanco-Canqui, H. and Lal, R.: Mechanisms of carbon sequestration in soil aggregates, CRC. Crit. Rev. Plant Sci., 23(6), 481-504, doi:10.1080/07352680490886842, 2004.

Van Breemen, N., Mulder, J. and Driscoll, C. .: Acidification and alkalinization of soils, Plant Soil, 75(3), 283-308 [online] Available from: http://www.jstor.com/stable/42934465, 1983.

Cerli, C., Celi, L., Kalbitz, K., Guggenberger, G. and Kaiser, K.: Separation of light and heavy organic matter fractions in soil - Testing for proper density cut-off and dispersion level, Geoderma, 170, 403-416, doi:10.1016/j.geoderma.2011.10.009, 4452012.

Chen, R., Senbayram, M., Blagodatsky, S., Myachina, O., Dittert, K., Lin, X., Blagodatskaya, E. and Kuzyakov, Y.: Soil C and $\mathrm{N}$ availability determine the priming effect: Microbial $\mathrm{N}$ mining and stoichiometric decomposition theories, Glob. Chang. Biol., 20(7), 2356-2367, doi:10.1111/gcb.12475, 2014.

Churchman, G. J. and Lowe, D. J.: Alteration, formation, and occurrence of minerals in soils, in Handbook of Soil Sciences,

450 vol. 1: Propert, edited by P. M. Huang, Y. Li, and M. E. Sumner, pp. 20.1-20.72, CRC Press (Taylor \& Francis), Boca Raton, FL., 2012.

De Clercq, T., Heiling, M., Dercon, G., Resch, C., Aigner, M., Mayer, L., Mao, Y., Elsen, A., Steier, P., Leifeld, J. and Merckx, R.: Predicting soil organic matter stability in agricultural fields through carbon and nitrogen stable isotopes, Soil Biol. Biochem., 88, 29-38, doi:10.1016/j.soilbio.2015.05.011, 2015.

455 Covaleda, S., Gallardo, J. F., García-Oliva, F., Kirchmann, H., Prat, C., Bravo, M. and Etchevers, J. D.: Land-use effects on the distribution of soil organic carbon within particle-size fractions of volcanic soils in the Transmexican Volcanic Belt (Mexico), Soil Use Manag., 27(2), 186-194, doi:10.1111/j.1475-2743.2011.00341.x, 2011.

Cronan, C. S.: Ecosystem Biogeochemistry, Springer. [online] Available from: http://link.springer.com/10.1007/978-3-31966444-6, 2018.

460 Cusack, D. F., Chadwick, O. A., Ladefoged, T. and Vitousek, P. M.: Long-term effects of agriculture on soil carbon pools 
https://doi.org/10.5194/soil-2022-13

Preprint. Discussion started: 24 February 2022

(c) Author(s) 2022. CC BY 4.0 License.

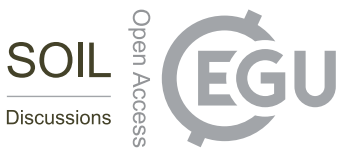

and carbon chemistry along a Hawaiian environmental gradient, Biogeochemistry, 112(1-3), 229-243, doi:10.1007/s10533012-9718-z, 2013.

Derrien, D., Plain, C., Courty, P. E., Gelhaye, L., Moerdijk-Poortvliet, T. C. W., Thomas, F., Versini, A., Zeller, B., Koutika, L. S., Boschker, H. T. S. and Epron, D.: Does the addition of labile substrate destabilise old soil organic matter?, Soil Biol.

Biochem., 76(November 2017), 149-160, doi:10.1016/j.soilbio.2014.04.030, 2014.

Doetterl, S., Stevens, A., Six, J., Merckx, R., Van Oost, K., Casanova Pinto, M., Casanova-Katny, A., Muñoz, C., Boudin, M., Zagal Venegas, E. and Boeckx, P.: Soil carbon storage controlled by interactions between geochemistry and climate, Nat. Geosci., 8(10), 780-783, doi:10.1038/ngeo2516, 2015.

Don, A., Schumacher, J. and Freibauer, A.: Impact of tropical land-use change on soil organic carbon stocks - a metaanalysis, Glob. Chang. Biol., 17(4), 1658-1670, doi:10.1111/j.1365-2486.2010.02336.x, 2011.

Dörner, J., Dec, D., Feest, E., Vásquez, N. and Díaz, M.: Dynamics of soil structure and pore functions of a volcanic ash soil under tillage, Soil Tillage Res., 125, 52-60, doi:10.1016/j.still.2012.05.019, 2012.

Du, Z. liu, Wu, W. liang, Zhang, Q. zhong, Guo, Y. bin and Meng, F. qiao: Long-Term Manure Amendments Enhance Soil Aggregation and Carbon Saturation of Stable Pools in North China Plain, J. Integr. Agric., 13(10), 2276-2285, doi:10.1016/S2095-3119(14)60823-6, 2014.

Dungait, J. A. J., Hopkins, D. W., Gregory, A. S. and Whitmore, A. P.: Soil organic matter turnover is governed by accessibility not recalcitrance, Glob. Chang. Biol., 18(6), 1781-1796, doi:10.1111/j.1365-2486.2012.02665.x, 2012.

Gerzabek, M. H., Bajraktarevic, A., Keiblinger, K., Mentler, A., Rechberger, M., Tintner, J., Wriessnig, K., Gartner, M., Valenzuela, X. S., Troya, A., Couenberg, P. M., Jäger, H., Carrión, J. E. and Zehetner, F.: Agriculture changes soil properties on the Galápagos Islands-two case studies, Soil Res., 57(3), 201-214, doi:10.1071/SR18331, 2019.

Gijsman, A. J. and Sanz, J. I.: Soil organic matter pools in a volcanic-ash soil under fallow or cultivation with applied chicken manure, Eur. J. Soil Sci., 49(3), 427-436, doi:10.1046/j.1365-2389.1998.4930427.x, 1998.

Hernández, Z., Almendros, G., Carral, P., Álvarez, A., Knicker, H. and Pérez-Trujillo, J. P.: Influence of non-crystalline minerals in the total amount, resilience and molecular composition of the organic matter in volcanic ash soils (Tenerife Island, Spain), Eur. J. Soil Sci., 63(5), 603-615, doi:10.1111/j.1365-2389.2012.01497.x, 2012.

Högberg, M. N., Högberg, P. and Myrold, D. D.: Is microbial community composition in boreal forest soils determined by pH, C-to-N ratio, the trees, or all three?, Oecologia, 150(4), 590-601, doi:10.1007/s00442-006-0562-5, 2007.

Huygens, D., Boeckx, P., Van Cleemput, O., Godoy, R. and Oyarzun, C.: Aggregate structure and stability linked to carbon dynamics in a south Chilean Andisol, Biogeosciences Discuss., 2(1), 203-238, doi:10.5194/bgd-2-203-2005, 2005.

490 Keeling, D.: The concentration and isotopic abundances of atmospheric carbon dioxide in rural areas, Geochim. Cosmochim. Acta, 13, 322-334, doi:https://doi.org/10.1016/0016-7037(58)90033-4, 1958.

de Kerchove, A. J. and Elimelech, M.: Formation of polysaccharide gel layers in the presence of $\mathrm{Ca} 2+$ and $\mathrm{K}+$ ions: Measurements and mechanisms, Biomacromolecules, 8(1), 113-121, doi:10.1021/bm060670i, 2007.

Kleber, M., Eusterhues, K., Keiluweit, M., Mikutta, C., Mikutta, R. and Nico, P. S.: Mineral-Organic Associations: 
https://doi.org/10.5194/soil-2022-13

Preprint. Discussion started: 24 February 2022

(c) Author(s) 2022. CC BY 4.0 License.

(c) (i)

495 Formation, Properties, and Relevance in Soil Environments, in Advances in Agronomy, vol. 130, edited by D. . Sparks, pp. 1-140, Elsevier Ltd., 2015.

Lehmann, J. and Kleber, M.: The contentious nature of soil organic matter, Nature, 528(7580), 60-68, doi:10.1038/nature16069, 2015.

Li, J., Du, J., Zhong, S., Ci, E. and Wei, C.: Changes in the profile properties and chemical weathering characteristics of cultivated soils affected by anthropic activities, Sci. Rep., 11(1), 1-11, doi:10.1038/s41598-021-00302-w, 2021.

Linlin, G., Taku, N., Hiromi, I. and Zhigang, S.: Carbon Mineralization Associated with Soil Aggregates as Affected by Short-Term Tillage, J. Resour. Ecol., 7(2), 101-106, doi:10.5814/j.issn.1674-764x.2016.02.004, 2016.

Liu, X. J. A., Sun, J., Mau, R. L., Finley, B. K., Compson, Z. G., van Gestel, N., Brown, J. R., Schwartz, E., Dijkstra, P. and Hungate, B. A.: Labile carbon input determines the direction and magnitude of the priming effect, Appl. Soil Ecol., 109, 7505 13, doi:10.1016/j.apsoil.2016.10.002, 2017.

Malik, A. A., Puissant, J., Buckeridge, K. M., Goodall, T., Jehmlich, N., Chowdhury, S., Gweon, H. S., Peyton, J. M., Mason, K. E., van Agtmaal, M., Blaud, A., Clark, I. M., Whitaker, J., Pywell, R. F., Ostle, N., Gleixner, G. and Griffiths, R. I.: Land use driven change in soil $\mathrm{pH}$ affects microbial carbon cycling processes, Nat. Commun., 9(1), 1-10, doi:10.1038/s41467-018-05980-1, 2018.

510 Matus, F., Rumpel, C., Neculman, R., Panichini, M. and Mora, M. L.: Soil carbon storage and stabilisation in andic soils: A review, Catena, 120, 102-110, doi:10.1016/j.catena.2014.04.008, 2014.

McKeague, J. A.: An evaluation of $0.1 \mathrm{M}$ pyrophosphate and pyrophosphate-dithionite in comparison with oxalate as extractants of the accumulation products in podzols and some other soils, Can. J. Soil Sci., 47(2), 95-99, doi:10.4141/cjss67017, 1967.

515 Mikha, M. M. and Rice, C. W.: Tillage and Manure Effects on Soil and Aggregate-Associated Carbon and Nitrogen, Soil Sci. Soc. Am. J., 68(3), 809-816, doi:10.2136/sssaj2004.8090, 2004.

Mikutta, R., Kleber, M., Torn, M. S. and Jahn, R.: Stabilization of soil organic matter: Association with minerals or chemical recalcitrance?, Biogeochemistry, 77(1), 25-56, doi:10.1007/s10533-005-0712-6, 2006.

Mikutta, R., Schaumann, G. E., Gildemeister, D., Bonneville, S., Kramer, M. G., Chorover, J., Chadwick, O. A. and

520 Guggenberger, G.: Biogeochemistry of mineral-organic associations across a long-term mineralogical soil gradient (0.3-4100 kyr), Hawaiian Islands, Geochim. Cosmochim. Acta, 73(7), 2034-2060, doi:10.1016/j.gca.2008.12.028, 2009.

Miyazawa, M., Takahashi, T., Sato, T., Kanno, H. and Nanzyo, M.: Factors controlling accumulation and decomposition of organic carbon in humus horizons of Andosols: A case study for distinctive non-allophanic Andosols in northeastern Japan, Biol. Fertil. Soils, 49(7), 929-938, doi:10.1007/s00374-013-0792-8, 2013.

525 Parfitt, R. L.: Allophane and imogolite: role in soil biogeochemical processes, Clay Miner., 44(1), 135-155, doi:10.1180/claymin.2009.044.1.135, 2009.

Paul, E. A., Morris, S. J., Six, J., Paustian, K. and Gregorich, E. G.: Interpretation of Soil Carbon and Nitrogen Dynamics in Agricultural and Afforested Soils, Soil Sci. Soc. Am. J., 67(5), 1620-1628, doi:10.2136/sssaj2003.1620, 2003. 
https://doi.org/10.5194/soil-2022-13

Preprint. Discussion started: 24 February 2022

(c) Author(s) 2022. CC BY 4.0 License.

(c) (i)

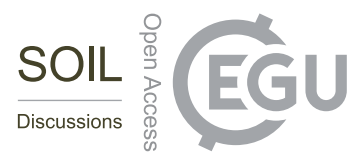

Poeplau, C., Don, A., Dondini, M., Leifeld, J., Nemo, R., Schumacher, J., Senapati, N. and Wiesmeier, M.: Reproducibility

of a soil organic carbon fractionation method to derive RothC carbon pools, Eur. J. Soil Sci., 64(6), 735-746, doi:10.1111/ejss.12088, 2013.

Poirier, V., Basile-Doelsch, I., Balesdent, J., Borschneck, D., Whalen, J. K. and Angers, D. A.: Organo-Mineral Interactions Are More Important for Organic Matter Retention in Subsoil Than Topsoil, Soil Syst., 4(1), 4, doi:10.3390/soilsystems4010004, 2020.

Qiao, N., Schaefer, D., Blagodatskaya, E., Zou, X., Xu, X. and Kuzyakov, Y.: Labile carbon retention compensates for CO2 released by priming in forest soils, Glob. Chang. Biol., 20(6), 1943-1954, doi:10.1111/gcb.12458, 2014.

Rabbi, S. M. F., Daniel, H., Lockwood, P. V., Macdonald, C., Pereg, L., Tighe, M., Wilson, B. R. and Young, I. M.: Physical soil architectural traits are functionally linked to carbon decomposition and bacterial diversity, Sci. Rep., 6(September), doi:10.1038/srep33012, 2016.

540 Six, J., Elliott, E. T. and Paustian, K.: Soil macroaggregate turnover and microaggregate formation: A mechanism for C sequestration under no-tillage agriculture, Soil Biol. Biochem., 32(14), 2099-2103, doi:10.1016/S0038-0717(00)00179-6, 2000a.

Six, J., Paustian, K., Elliott, E. T. and Combrink, C.: Soil Structure and Organic Matter I. Distribution of Aggregate-Size Classes and Aggregate-Associated Carbon, Soil Sci. Soc. Am. J., 64(2), 681-689, doi:10.2136/sssaj2000.642681x, $2000 \mathrm{~b}$.

545 Six, J., Conant, R. T., Paul, E. A. and Paustian, K.: Stabilization mechanisms of soil organic matter: Implications for Csaturation of soils, Plant Soil, 241(2), 155-176, doi:10.1023/A:1016125726789, 2002.

Six, J., Bossuyt, H., Degryze, S. and Denef, K.: A history of research on the link between (micro)aggregates, soil biota, and soil organic matter dynamics, Soil Tillage Res., 79(1), 7-31, doi:10.1016/j.still.2004.03.008, 2004.

Smith, W. ., Cleveland, C. ., Reed, S. . and Running, S. .: Agricultural conversion without external water and nutrient inputs reduces terrestrial vegetation productivity, Geophys. Prospect., (April), 6298-6305, doi:10.1002/2013GL058857.Received, 2014.

Taylor, M. D., Lowe, D. J., Hardi, P., Smidt, G. A. and Schnug, E.: Comparing volcanic glass shards in unfertilised and fertilised Andisols derived from rhyolitic tephras, New Zealand: Evidence for accelerated weathering and implications for land management, Geoderma, 271(November 2018), 91-98, doi:10.1016/j.geoderma.2016.01.035, 2016.

555 Wagai, R., Kajiura, M., Uchida, M. and Asano, M.: Distinctive roles of two aggregate binding agents in allophanic andisols: Young carbon and poorly-crystalline metal phases with old carbon, Soil Syst., 2(2), 1-23, doi:10.3390/soilsystems2020029, 2018.

Wei, X., Shao, M., Gale, W. and Li, L.: Global pattern of soil carbon losses due to the conversion of forests to agricultural land, Sci. Rep., 4, 6-11, doi:10.1038/srep04062, 2014.

560 Werth, M. and Kuzyakov, Y.: 13C fractionation at the root-microorganisms-soil interface: A review and outlook for partitioning studies, Soil Biol. Biochem., 42(9), 1372-1384, doi:10.1016/j.soilbio.2010.04.009, 2010.

Yu, H., Ding, W., Luo, J., Geng, R., Ghani, A. and Cai, Z.: Effects of long-term compost and fertilizer application on 
https://doi.org/10.5194/soil-2022-13

Preprint. Discussion started: 24 February 2022

(C) Author(s) 2022. CC BY 4.0 License.

(c) (1)

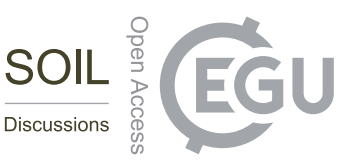

stability of aggregate-associated organic carbon in an intensively cultivated sandy loam soil, Biol. Fertil. Soils, 48(3), 325336, doi:10.1007/s00374-011-0629-2, 2012.

565 Zheng, H., Liu, W., Zheng, J., Luo, Y., Li, R., Wang, H. and Qi, H.: Effect of long-term tillage on soil aggregates and aggregate-associated carbon in black soil of northeast China, PLoS One, 13(6), 1-18, doi:10.1371/journal.pone.0199523, 2018.

Zimmermann, M., Leifeld, J., Schmidt, M. W. I., Smith, P. and Fuhrer, J.: Measured soil organic matter fractions can be related to pools in the RothC model, Eur. J. Soil Sci., 58(3), 658-667, doi:10.1111/j.1365-2389.2006.00855.x, 2007. 